\title{
Gród w Ostrowitem (Napolu) na ziemi chelmińskiej - od centrum opolnego do włości rycerskiej
}

\author{
Stronghold in Ostrowite (Napole) in Chelmno Land - \\ from opole centre to knight estate
}

Zarys treści. Struktury osadnicze wykształcone na początku wczesnego średniowiecza nad jeziorem Oszczywilk stanowiły aż do końca XIII wieku ważne centrum wspólnoty sąsiedzko-terytorialnej. Rozwojowi tej jednostki osadniczej, której głównym ogniwem stał się powstały w 2. połowie $\mathrm{X}$ wieku gród, sprzyjało strategiczne położenie na pograniczu głównych prowincji historyczno-geograficznych oraz bliskość ważnych szlaków komunikacyjnych, w tym Drwęcy. Ewolucja tego zespołu przebiegała od niewielkiego skupiska mikroregionalnego przez czoło opolne, do centrum administracyjnego i gospodarczego państwowego, a w końcu biskupiego, w ramach klucza ostrowicko-golubskiego, wreszcie siedziby rycerskiej.

Slowa kluczowe: wczesne średniowiecze, struktury osadnicze ziemia chełmińska, gród w Ostrowitem, centrum plemienne i osadnicze, dobra ostrowicko-golubskie.

\section{UWAGI WSTĘPNE}

Podróżując z Kowalewa Pomorskiego do Golubia-Dobrzynia nie sposób nie zauważyć dominującego w krajobrazie grodziska w Napolu. Obiekt ten z dobrze zachowanymi reliktami wałów drewniano-ziemnych, położony wśród pól uprawnych, od dawna budził zainteresowanie badaczy zajmujących się przeszłością ziemi chełmińskiej (ryc. 1). Znany ze źródeł pisanych gród w Ostrowitem (dzisiaj w granicach wsi Napole) stanowił aż po koniec XIII wieku centrum osadnicze jednej z największych na ziemi chełmińskiej wspólnot terytorialnych, sięgającej swymi wpływami aż po Drwęcę. Dopiero w czasach krzyżackich jego rolę 


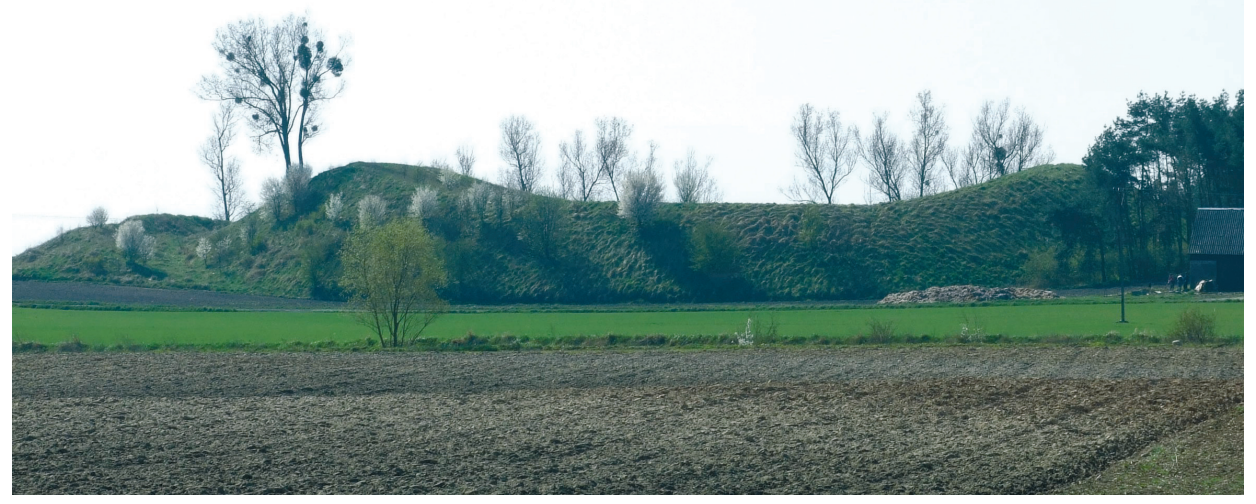

Ryc. 1. Napole (Ostrowite), gm. Kowalewo Pomorskie. Widok grodziska od północy (fot. J. Bojarski)

Fig. 1. Napole (Ostrowite), Kowalewo Pomorskie commune. View of the stronghold from the north (photo J. Bojarski)

przejęły pobliskie Kowalewo i naddrwęcki Golub. Wykształcenie się w tym miejscu już w początkach wczesnego średniowiecza struktur osadniczych pozostawało w związku z procesami osadniczymi zachodzącymi w okolicach południowego odcinka dorzecza Drwęcy (Chudziak 1993). Sprzyjało temu korzystne pod wieloma względami położenie na styku dwóch prowincji historyczno-geograficznych, jakimi we wczesnym średniowieczu były ziemia chełmińska - powiązana kulturowo i osadniczo, początkowo ze strefą pomorską, następnie wielkopolsko-kujawską, wreszcie też mazowiecką - oraz ziemia dobrzyńska, związana z Mazowszem. Korzystnie na rozwój tego ośrodka oddziaływały lokalne i interregionalne szlaki komunikacyjne, których przebieg przez tereny ostrowickiego zespołu osadniczego rekonstruować można na podstawie źródeł pisanych i archeologicznych (Chudziak 1997a; 1997b).

\section{LOKALIZACJA}

Ostrowicki zespół osadniczy, w którego skład wchodzą grodzisko, dwie rozległe osady podgrodowe i cmentarzysko szkieletowe, usytuowany jest na grzbiecie wału kemowego ciągnącego się na linii północny zachód-południowy wschód, długości ponad $700 \mathrm{~m}$ i szerokości dochodzącej do $100 \mathrm{~m}$ (ryc. 2); wysokość względna wału wynosi od $5 \mathrm{~m}$ w części wschodniej do $10 \mathrm{~m}$ w części zachodniej (Poliński 1994, s. 115 i nn.). W jego obrębie można wyróżnić dwie części: wschodnią (mniejszą), na której znajduje się grodzisko (stanowisko 3) oraz zachodnią - z osadą i cmentarzyskiem (stanowisko 6). Rozdziela je lekkie, 
rynnowate obniżenie, które być może powstało w trakcie sypania wałów grodu (ryc. 3). Zbudowany z piasków i żwirów kem leży w przykrawędziowej części wysoczyzny morenowej płaskiej o wysokości około 90 m n.p.m. Od południa przylega do niego rynna subglacjalna, w której dnie znajduje się jezioro Oszczywilk oraz szereg niecek i rynien wypełnionych osadami biogenicznymi. Liczne zagłębienia wytopiskowe znajdują się w obrębie otaczającej kem wysoczyzny morenowej; w przeszłości zapewniały one łatwy dostęp do wód powierzchniowych. Przy południowo-wschodnim końcu jeziora Oszczywilk przebiega wąska rynna subglacjalna o długości około $6 \mathrm{~km}$, której ujście znajduje się w korycie Drwęcy, 1,5 km na zachód od centrum Golubia. Ciąg rynien widoczny jest po północno-zachodniej stronie zespołu osadniczego, pomiędzy jeziorem a równiną biogeniczną, na wschód od Kowalewa Pomorskiego, od którego grodzisko dzieli odległość $4 \mathrm{~km}$. W bezpośrednim otoczeniu stanowisk występują żyzne gleby brunatne, wykształcone na piaskach słabo gliniastych, od północy zaś płat czarnych ziem właściwych.

\section{HISTORIA BADAŃ}

Nazwa grodu Ostrowith po raz pierwszy zapisana została w dłuższej wersji przywileju z Lonyz (wersja A), uznawanej za krzyżackie fałszerstwo z 1240 roku (Bieniak 1970, s. 12-24; Powierski 1973a). Dokument ten miał w intencji Krzyżaków potwierdzać ich prawa do naddrwęckiej części ziemi chełmińskiej. Oprócz wymienionych w wersji B (oryginalnej z 1222/1223 roku) byłych grodów położonych w zachodniej części ziemi chełmińskiej, zawiera spis dodatkowych 13 miejscowości z prawobrzeża Drwęcy, jakoby przekazanych biskupowi Chrystianowi przez księcia mazowieckiego Konrada (Chudziak 1996a, s. 26 i nn.; Janowski 2007, s. 278 i nn.). Wśród tych niegdyś grodów (quondam castra) wystąpiły w tym dokumencie Ostrowite, Kowalewo ${ }^{1}$, Bielsk (Belyz) ${ }^{2}$ i Chełmonie ${ }^{3}$. Kolejne powstałe w ciągu XIII stulecia dokumenty, w których pojawiała się nazwa Ostrowitego, dobrze poświadczają funkcjonowanie jednorodnego i zwartego kompleksu dóbr ostrowickich, którego podstawy ukształtowane zostały w okresie plemiennym

${ }^{1}$ W tej miejscowości nie stwierdzono jakichkolwiek pozostałości założenia obronnego ze wspomnianego okresu (Bojarski, Gurtowski 1994).

${ }^{2}$ Miejscowość Belyz przez historyków najczęściej odczytywana jest jako Bielsk, położony 2 kilometry na południe od Kowalewa Pomorskiego, jednak brak jest wyraźnych przesłanek archeologicznych do potwierdzenia takiej właśnie lokalizacji (w miejscowości tej nie odnaleziono reliktów grodu datowanego na opisywany okres). Stąd ostatnio przeważa pogląd, że nazwę tę powinno się odnosić do wsi Bielczyny, na terenie której znajduje się późnośredniowieczne grodzisko (Kola 1991, s. 151 i nn.; Poliński 2003, s. 175).

${ }^{3} \mathrm{Z}$ miejscowości tej znane jest późnośredniowieczne grodzisko stożkowate, wielokrotnie wzmiankowane w dokumentach historycznych (Kola 1991, s. 156-158). 


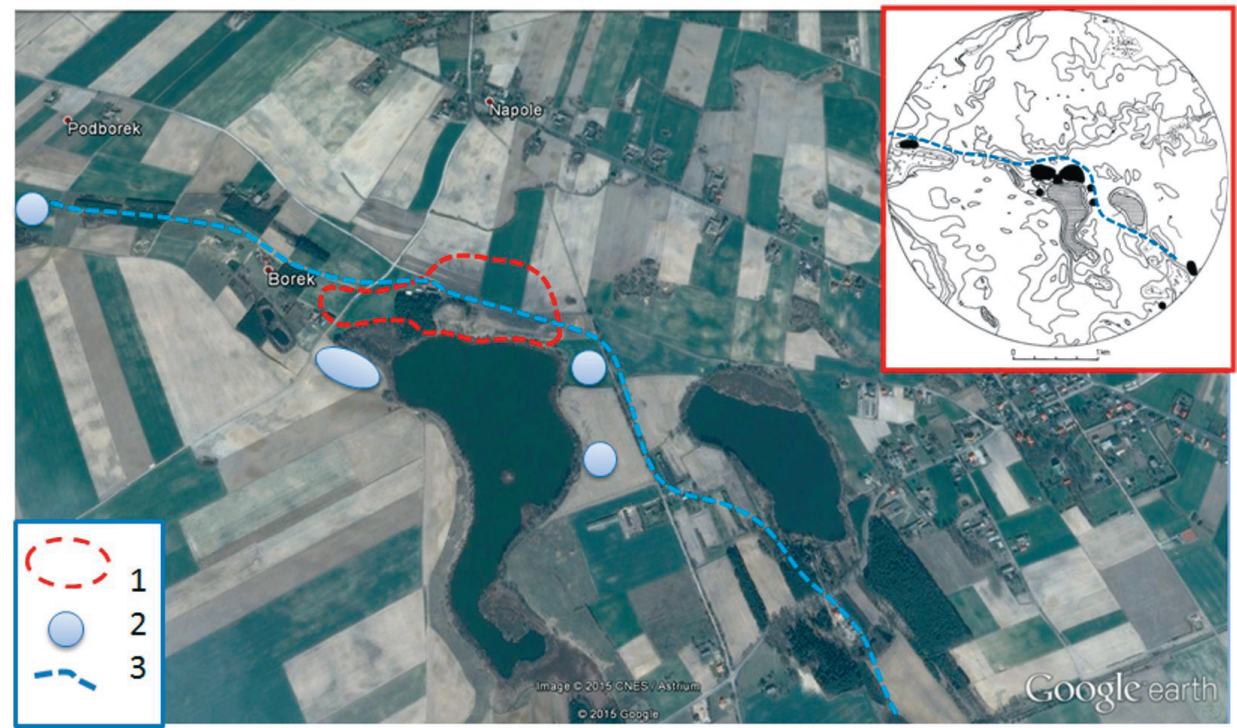

Ryc. 2. Mikroregion osadniczy w Napolu, gm. Kowalewo Pomorskie (wg Google Earth; rys. J. Bojarski)

Fig. 2. Settlement microregion in Napole, Kowalewo Pomorskie commune (after Google Earth; drawing by J. Bojarski)

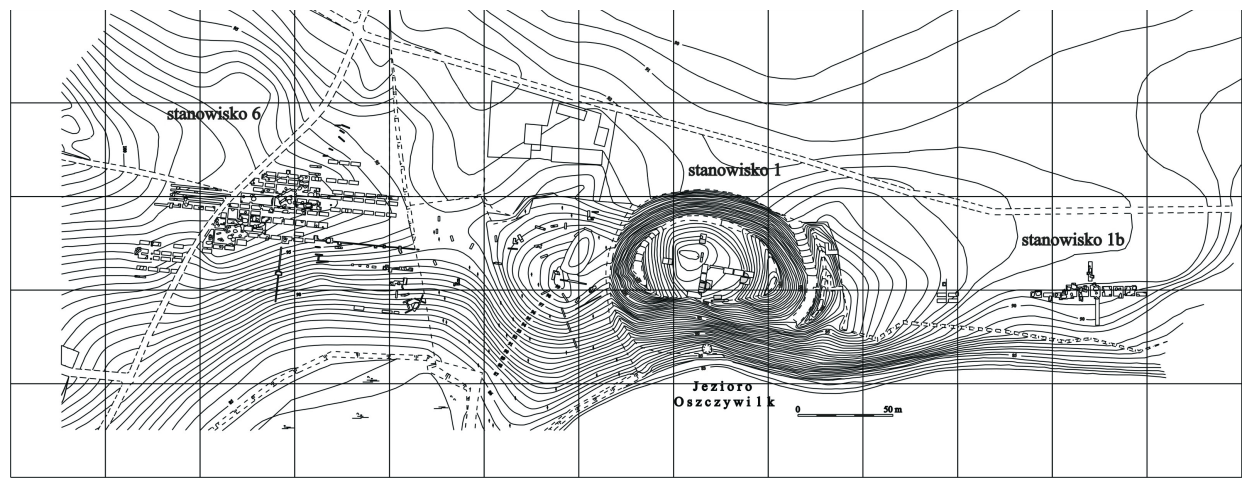

Ryc. 3. Napole, gm. Kowalewo Pomorskie. Plan wczesnośredniowiecznego zespołu osadniczego (rys. M. Mierzejewski, J. Bojarski)

Fig. 3. Napole, Kowalewo Pomorskie commune. Plan of early medieval settlement complex (drawing by M. Mierzejewski and J. Bojarski)

(na ten temat - por. Powierski 1973b; 1977 - tam również literatura). Do tych zapisów przyjdzie nam jeszcze powrócić.

Do literatury grodzisko w Ostrowitem (dziś grunty wsi Napole) weszło za sprawą Gotfryda Ossowskiego (1878, s. 21) i Abrahama Lissauera (1887, s. 185). $\mathrm{Na}$ jego temat pisał Władysław Łęga (1930, s. 594), wspominając przy okazji o konstrukcjach drewnianych znajdujących się w strefie przybrzeżnej jeziora. 
Częste zmiany granic administracyjnych wsi, na gruntach której znajduje się grodzisko, doprowadziły do omyłkowego rozmnożenia liczby grodzisk, stąd w starszej literaturze podawano lokalizację odnoszoną do Gajewa i Ostrowitego, w którym wymieniano dwa obiekty (np. Powierski 1977, s. 35; por. też Bojarski, Gurtowski 1994, tab. 1). Pierwsze badania wykopaliskowe o charakterze sondażowym przeprowadził na grodzisku w 1976 roku Andrzej Kola z Instytutu Archeologii i Etnografii Uniwersytetu Mikołaja Kopernika w Toruniu (Kola 1991, s. 182-185). Powtórne badania sondażowo-weryfikacyjne pod kierunkiem Wojciecha Chudziaka z tego samego ośrodka miały miejsce w 1989 roku, najpierw na grodzisku, a w następnym roku również na położonej po zachodniej stronie osadzie otwartej (stanowisko 6). Obiecujące wyniki zdecydowały o rozpoczęciu w 1991 roku systematycznych prac wykopaliskowych, które objęły w ciągu kolejnych trzech lat grodzisko i dwie osady położone po zachodniej (stanowisko 6) i wschodniej stronie wałów (stanowisko 1b) (Bojarski, Łukasiak 1993; Poliński 1994; Stawska 1993; 2003, s. 98-100). Rozpoznanie sondażowe przeprowadzono także na niewielkiej osadzie położonej po południowej stronie rynny jeziornej (stanowisko 15 w Chełmońcu ${ }^{4}$ ) (Bojarski 2012, s. 11-26).

Grodzisko, położone centralnie w ramach całego kompleksu osadniczego, jest jednoczłonowe, z czytelną na niemal całym obwodzie linią wałów elipsoidalnego kształtu (ryc. 4). Po wschodniej stronie znajduje się podkowiasty wał odcinkowy, stanowiący w przeszłości zapewne dodatkową osłonę drogi dojazdowej. W południowej części grodziska wyraźnie widoczne jest obniżenie wału - ślad po dawnej bramie. Wysokość wału w stosunku do poziomu jeziora wynosi 18-24 m, natomiast względem przyległej od północy części wysoczyzny dochodzi do ponad $10 \mathrm{~m}$. Podstawa grodziska zajmuje powierzchnię $5400 \mathrm{~m}^{2}$ (wliczając wał dodatkowy), z czego na majdan przypada $900 \mathrm{~m}^{2}$. We wszystkich wykopach wytyczonych na grodzisku natrafiono na skomplikowane układy warstw wczesnośredniowiecznych oraz zalegających powyżej, uformowanych w późnym średniowieczu; ich miąższość miejscami osiągała 5 m (Poliński 1994, s. 118-120; Bojarski 2012, s. 13 i nn.). Z okresu wczesnośredniowiecznego pochodzą znajdujące się w strefie podwałowej relikty dookolnej zabudowy, związanej konstrukcyjnie z wałem, częściowo zagłębionej poniżej poziomu majdanu. Głównie na podstawie analizy stratygrafii oraz pochodzących z warstw grodziska serii naczyń ceramicznych wyróżniono pięć faz użytkowania obiektu, datowanych od 2. połowy X do 1. ćwierci XIII wieku (Bojarski 2012, s. 95, tab. 30). Słabiej zachowane były pozostałości zabudowy z późnego średniowiecza, które miały demolacyjny charakter. Na podstawie analizy pochodzących z nich naczyń ceramicznych datowane są na 2. połowę XIII do XIV wieku; węższe ramy czasowe - od 4. ćwierci XIII do 1. połowy

${ }^{4}$ Natrafiono tu jedynie na nawarstwienia powstałe w późnym średniowieczu, niemniej z powierzchni stanowiska $i$ warstwy ornej zebrano znaczną liczbę ułamków wczesnośredniowiecznych naczyń ceramicznych, świadczących o eksploatacji tego terenu w okresie funkcjonowania ostrowickiego zespołu osadniczego we wczesnym średniowieczu. 


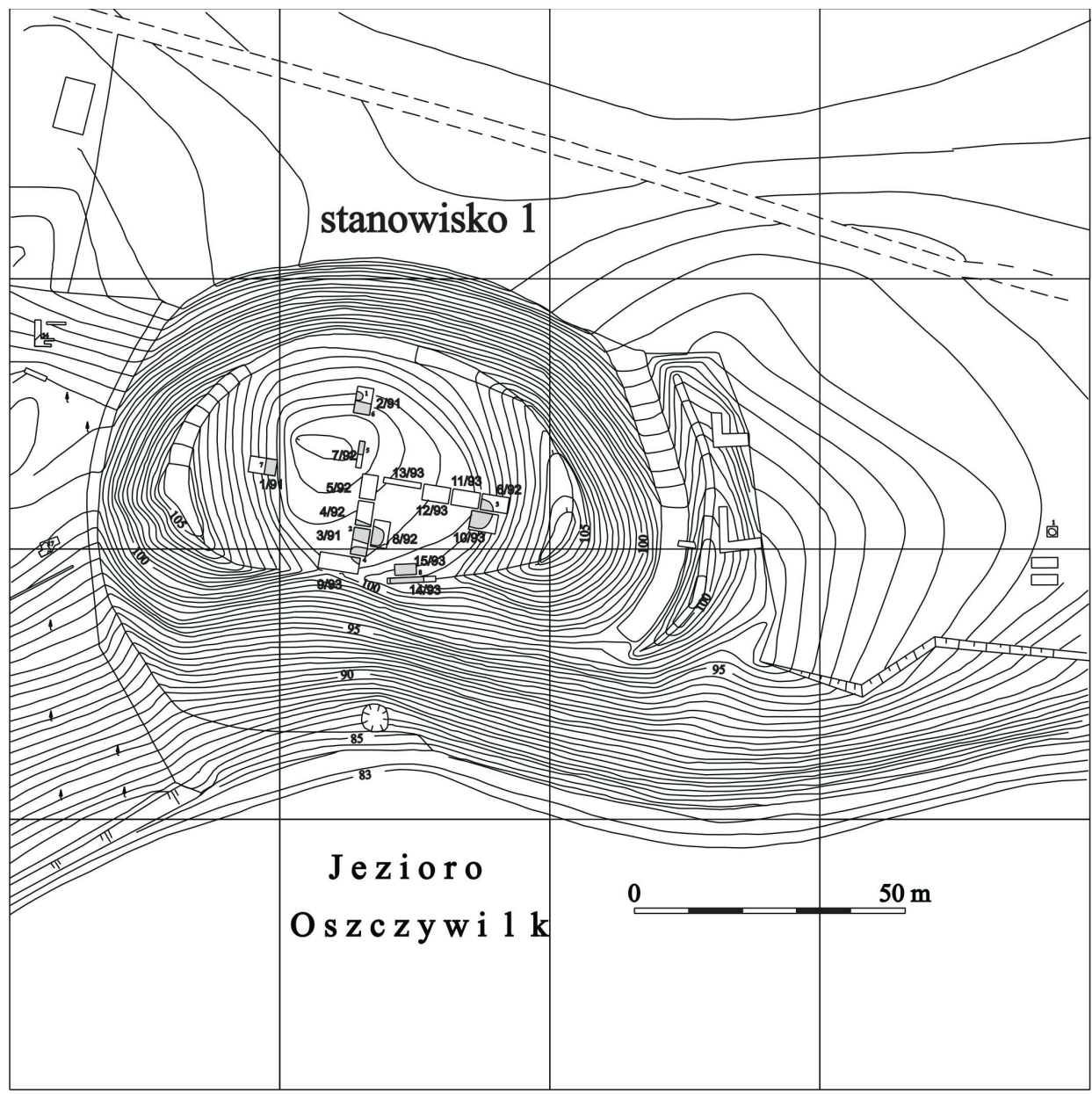

Ryc. 4. Napole, gm. Kowalewo Pomorskie, stanowisko 1. Planigrafia grodziska (rys. M. Mierzejewski, J. Bojarski)

Fig. 4. Napole, Kowalewo Pomorskie commune, site 1. Plan of the stronghold (drawing by M. Mierzejewski and J. Bojarski)

XIV wieku - zaproponował Dariusz Poliński (1996, s. 173 i nn.). W południowej strefie majdanu odsłonięto pozostałości przejścia bramnego, z dobrze czytelnymi czterema poziomami jezdnymi - trzema z wczesnego średniowiecza i jednym późnośredniowiecznym (Bojarski 2012, ryc. 8).

Położona po zachodniej stronie grodziska osada (stanowisko 6) zajmuje teren rozciągający się na przestrzeni $250 \mathrm{~m}$, podzielony na dwie odrębne części - wschodnią bezpośrednio przy wale grodziska (obecnie porośniętą lasem), na lekko wypiętrzonym w tym miejscu wzgórzu kemowym, oraz rozleglejszą - zachodnią, rozciągniętą głównie wzdłuż grzbietu pagórka na odcinku prawie 200 m (ryc. 5). 


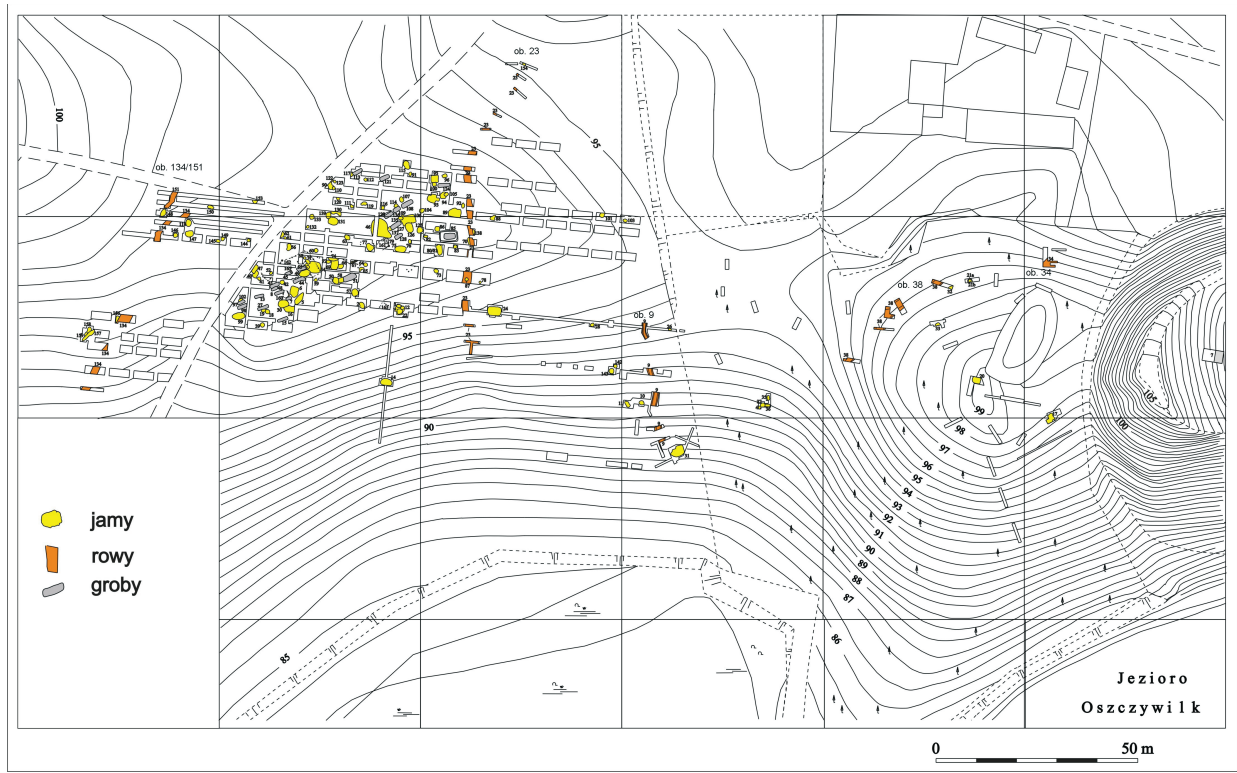

Ryc. 5. Napole, gm. Kowalewo Pomorskie, stanowisko 6. Planigrafia osady zachodniej z odkrytymi jamami wczesnośredniowiecznymi (rys. M. Mierzejewski, J. Bojarski)

Fig. 5. Napole, Kowalewo Pomorskie commune, site 6. Plan of western settlement with discovered early medieval pits (drawing by M. Mierzejewski and J. Bojarski)

W ciągu czterech lat badań rozpoznano obszar liczący 20 arów (około 10\% szacowanej powierzchni), przede wszystkim część zachodnią osady (Bojarski 2012, s. 23 i nn.). W sumie odkryto 116 obiektów stanowiących pozostałości zabudowy naziemnej i wziemnej o charakterze mieszkalno-gospodarczym, reprezentujących wszystkie fazy wczesnego średniowiecza (2. połowa VII-początek XIII wieku). Zasadniczą część zabudowy ograniczały dwa poprzeczne rowy (obiekty 23 i 134), mające charakter odcinkowy. Pozostałości rowów odkryto także we wschodniej części osady, bliżej grodziska (obiekty 34 i 9), które funkcję rozgraniczającą pełniły we wczesnym, a także w późnym średniowieczu. Oprócz jam osadniczych zadokumentowano przykrywające znaczną powierzchnię stanowiska warstwy kulturowe, których powstanie można wiązać zarówno z wczesnym, jak i późnym średniowieczem. Na mniejszym pagórku kemowym, bezpośrednio przy wałach grodziska oraz na północnym stoku większego pagórka odsłonięto pojedyncze jamy zawierające ułamki późnośredniowiecznych naczyń ceramicznych, przykryte warstwami o znacznej miąższości, datowanymi również na późne średniowiecze. W zachodniej części osady, na terenie ograniczonym rowami, odkryto 24 groby szkieletowe w układzie rzędowym, zajmujące pas o szerokości $12 \mathrm{~m}$ i długości 
70 m (ryc. 6); ich chronologię określono na schyłek XI-XII wieku (Stawska 2003; s. 89-108; Bojarski 2014) .

Osada wschodnia (stanowisko 1b) zajmuje skrajną, wschodnią część pagórka, najmniej eksponowaną oraz przyległy do niego teren, położony bezpośrednio przy niecce jeziornej. Badaniami archeologicznymi rozpoznano tylko niewielki pas o długości ponad 100 i szerokości $10 \mathrm{~m}$, na którym odkryto występujące w dużym zagęszczeniu 34 jamy, głównie o charakterze gospodarczym, z materiałem reprezentującym pełen przekrój wytwórczości garncarstwa wczesnośredniowiecznego. Powierzchnię zabudowy rozdzielał znacznej szerokości i głębokości rów pochodzący z młodszego odcinka dziejów tego osiedla (obiekt 20). O rozległości osiedla we wczesnym średniowieczu świadczą masowo występujące na jego powierzchni ułamki naczyń ceramicznych, oraz nasycenie warstwy ornej spalenizną i węglami drzewnymi, pochodzącymi z niszczonych stropowych części jam osadniczych. Efektem tego jest powstanie wyróżnika glebowego - silnego przebarwienia warstwy powierzchniowej (co widoczne jest na zdjęciach lotniczych) (Bojarski 2012, s. 25-26).

\section{ZASIEDLENIE MIKROREGIONU}

Przeprowadzona po zakończeniu badań terenowych analiza dynamiki procesów osadniczych zachodzących w zespole ostrowicko-napolskim we wczesnym średniowieczu była punktem wyjścia do określenia relacji funkcjonalno-przestrzennych reliktów zabudowy odkrytych na terenie grodziska i przyległych osad $^{6}$. Wymiernym efektem tych prac jest obszerna monografia poświęcona wytwórczości garncarskiej jako źródłu poznania procesów osadniczych zachodzących w mikroregionie (Bojarski 2012, s. 306-317). Omawiając pokrótce dzieje tego centrum osadniczego, odwołam się do głównych wniosków zawartych we wspomnianej pracy.

Początek zasiedlenia mikroregionu przypadł na 2. połowę VII wieku (ryc. 7: A). W pierwszej kolejności zajęto teren położony nad płytkimi zatoczkami jeziora po jego wschodniej, a następnie zachodniej stronie. Trudno powiedzieć czy oba wydzielone skupiska obiektów stanowiły jedno osiedle, czy może dwa osobne. Niewykluczone, że część jam z tej fazy została zniszczona w trakcie późniejszej o kilka stuleci budowy grodu. Od VIII do 1. połowy IX wieku znacznie zwiększyła się

\footnotetext{
${ }^{5}$ Przeprowadzona ostatnio bardziej szczegółowa analiza wyposażenia grobowego, a także relacji stratygraficznych jam grobowych i reliktów zabudowy osiedla wskazują na wcześniejszy okres funkcjonowania tej nekropoli niż ten, który podawano w starszych opracowaniach (Stawska 1993, s. $143 ; 2003$, s. 100$)$.

${ }^{6}$ Wstępną, jeszcze przed ukończeniem prac badawczych, analizę przemian w rozwoju przestrzennym mikroregionu napolskiego przeprowadził Wojciech Chudziak, ukazując Napole na szerszym tle osadniczym dorzecza dolnej Drwęcy (Chudziak 1993).
} 


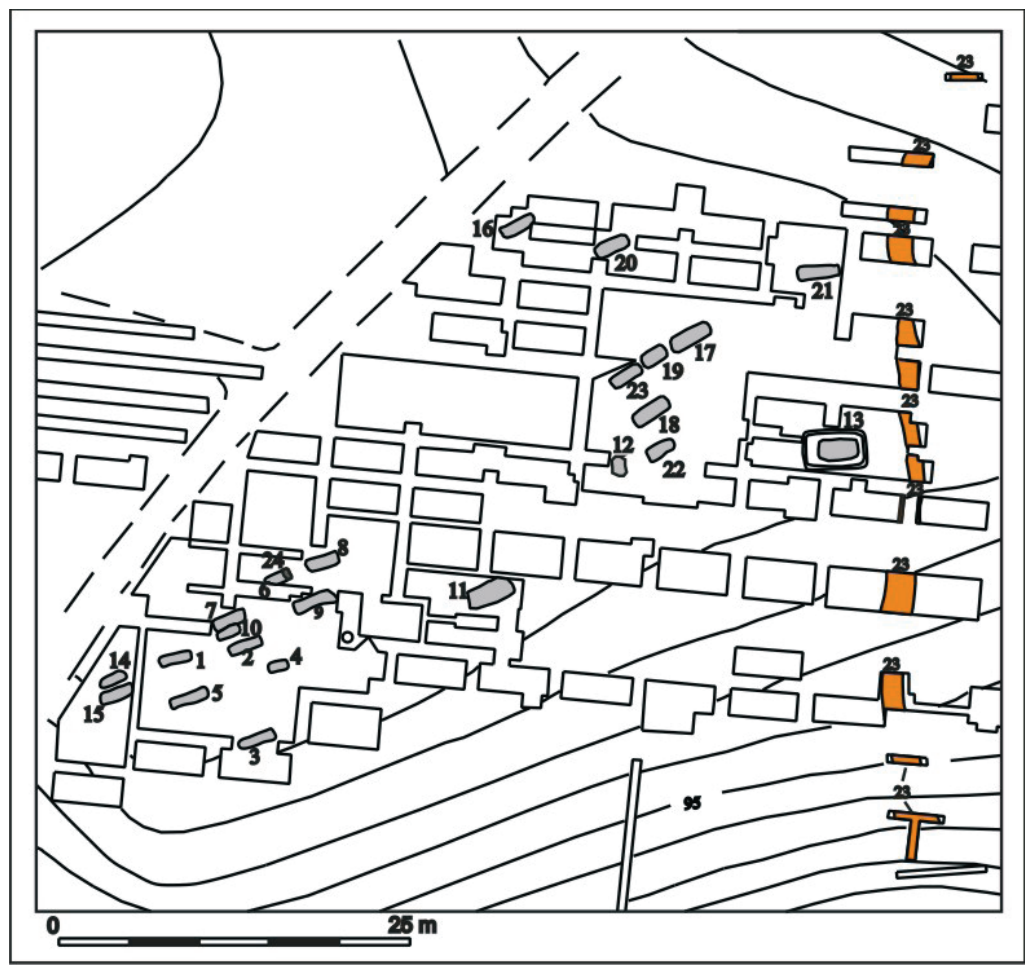

Ryc. 6. Napole, gm. Kowalewo Pomorskie, stanowisko 6. Planigrafia grobów (rys. J. Bojarski)

Fig. 6. Napole, Kowalewo Pomorskie commune, site 6. Plan of graves (drawing J. Bojarski)

powierzchnia obu osiedli. W jednym i drugim przypadku granice zabudowy uległy przesunięciu w kierunku zachodnim. We wschodniej części kompleksu osadniczego utrzymał się bardziej luźny charakter zabudowy. Na zewnątrz przestrzeni mieszkalnej, bliżej jeziora, znajdowały się obiekty o charakterze gospodarczym. We wspomnianym okresie zapewne w sztuczny sposób zaczęto ograniczać przestrzeń zachodniego osiedla. W północno-zachodniej jego części powstał rów (obiekt 151), który w IX-1. połowie X wieku przedłużono w kierunku południowym (obiekt 134). Wyznaczona w ten sposób granica okazała się na tyle stabilna, że nie została przekroczona w żadnej z kolejnych faz rozwoju osiedla. Wyraźne zmiany w jego przestrzennej organizacji zaszły w 2. połowie IX-1. połowie X wieku; znacznie powiększyła się użytkowana powierzchnia. W części zachodniej zabudowa mieszkalna i gospodarcza tworzyła otwarte od południa półkole (skierowane ku zatoce jeziora) z pustym w środku placem; powierzchnia zachodniego osiedla wynosiła ponad 0,5 ha. Był to jednocześnie okres, w którym nastąpił postęp w wielu dziedzinach związanych między innymi z wytwórczością 


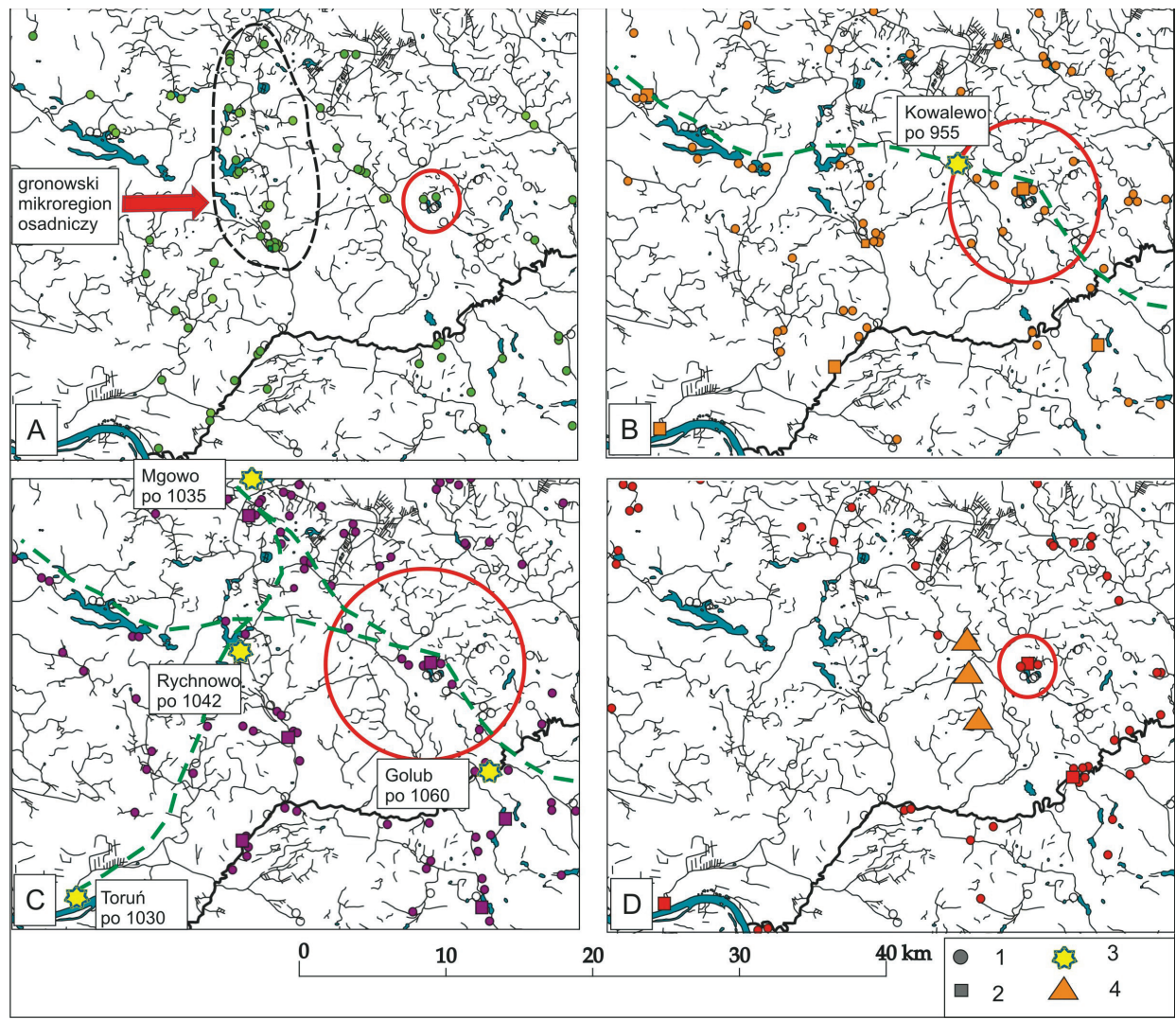

Ryc. 7. Etapy rozwoju zasiedlenia mikroregionu na tle wczesnośredniowiecznych struktur osadniczych dorzecza dolnej Drwęcy. A - VII-VIII wiek, B - IX-X/XI wieku, C - XI-XI/XII wieku, D - XII-1. ćwierć XIII wieku. Legenda: 1 - osady otwarte i domniemane, 2 - grodziska, 3 - skarby, 4 - quondam castra $\mathrm{z}$ wersji A przywileju z Lonyz (Kowalewo, Bielsk? i Chełmonie) (wg Chudziak 1996 z uzupełnieniami autora)

Fig. 7. Stages of microregion settlement development against the background of early medieval settlement structures of the lower Drwęca River basin. A $-7^{\text {th }}-8^{\text {th }}$ century, B $-9^{\text {th }}-10^{\text {th }} / 11^{\text {th }}$ century, $C-11^{\text {th }}-11^{\text {th }} / 12^{\text {th }}$ century, D $-12^{\text {th }}-$ first quarter of the $13^{\text {th }}$ century. Legend: 1 - open and suspected settlements, 2 - strongholds, 3 - hoards, 4 - quondam castra from version A of privilege of Lonyz (Kowalewo, Bielsk? and Chełmonie) (after Chudziak 1996 with author's supplements)

garncarską (lepszej jakości naczynia wykonane z użyciem koła garncarskiego; ryc. 8), rogowniczą (nowe, bardziej zróżnicowane formy przedmiotów z poroża i kości) czy też metalurgiczną (zróżnicowany zestaw narzędzi żelaznych, żużle kowalskie oraz pozostałości pieców wykorzystywanych prawdopodobnie w obróbce termicznej żelaza). Na ten właśnie czas można datować wykształcenie 
się wokół centrum osadniczego w Ostrowitem wspólnoty opolnej typu civitates (znanej z tzw. Geografa Bawarskiego), wyraźnie odseparowanej pasami pustek osadniczych o szerokości ponad $5 \mathrm{~km}$ od sąsiednich struktur terytorialnych, położonych po zachodniej i północnej stronie. Zasięg jej oddziaływań obejmował około $90 \mathrm{~km}^{2}$ (Chudziak 1996b, tab. 36, mapy 2 i 3). W tym przypadku rolę ośrodka centralnego pełniło - zajmujące znaczną powierzchnię - zachodnie osiedle, wydzielone z przestrzeni poprzecznymi rowami. Zapewne okolicznością sprzyjającą rozwojowi tej wspólnoty był rozpad struktur osadniczych skupionych wokół grodu w Gronowie, funkcjonującego w VIII wieku. Rozwój demograficzny lokalnej wspólnoty owocował zakładaniem w niewielkiej odległości od jeziora Oszczywilk nowych osiedli, których liniowy układ wyraźnie nawiązuje do przebiegu szlaku komunikacyjnego łączącego późniejszą ziemię dobrzyńską z ziemią chełmińską (ryc. 7: B). W ten sposób, w odległości 1,5 km na zachód od centrum mikroregionu, powstała duża osada w obecnej miejscowości Pluskowęsy. Jej funkcjonowanie było zapewne związane z traktem prowadzącym w kierunku Pomorza.

Na początku X wieku, lub nieco później, miało miejsce przedłużenie formującego się między Pomorzem a ziemią chełmińską szlaku handlowego, prowadzącego przez północne Mazowsze w kierunku Rusi Kijowskiej, alternatywnego dla połączenia morskiego (Łosiński 2002, s. 188). Nastąpiło to dzięki uruchomieniu wodno-lądowego szlaku prypecko-bużańskiego, którym od początku X wieku transportowano srebro do Wielkopolski oraz na Pomorze (Lewicki 1972, s. 8; Łosiński 1988, s. 141). Potwierdzeniem istnienia tej nowej drogi handlowej jest skarb monet odkryty w okolicy Kowalewa Pomorskiego, zdeponowany po roku 954/955 (Kiersnowscy 1959, s. 59-60). Jego jednolita struktura, zdominowana przez dirhemy samanidzkie, jest charakterystyczna dla zespołów monet napływających na ziemie zachodniosłowiańskie w młodszej fazie dystrybucji srebra kufickiego (Kowalewski 2003, s. 153). Do skarbu tego nawiązują inne depozyty układające się na linii południowy wschód - północny zachód, począwszy od Balina niedaleko Rypina (po 952 roku), przez Kowalewo do Uścia koło Kałdusa (po 971 roku). Tak wytyczony szlak przebiegałby przez główne czoła opolne typu civitates z ziemi dobrzyńskiej i ziemi chełmińskiej, znajdujące się w Borzyminie, Ostrowitem-Napolu, Chełmży, Chełmnie i Grucznie, następnie przez Wysoczyznę Świecką, docelowo w kierunku Kołobrzegu (Chudziak 1997a, s. 107, ryc. 1). Na odcinku między Kowalewem a Borzyminem jego przebieg można rekonstruować na podstawie liniowego układu osiedli wzdłuż dwóch rynien, którymi płyną Ruziec (od strony ziemi dobrzyńskiej) i Struga Młyńska (od strony ziemi chełmińskiej), z przeciwnych stron uchodzące do Drwęcy w mniej więcej tym samym miejscu. Kierunek przepływu dóbr na tym szlaku był zapewne dwukierunkowy, chociaż stroną aktywniejszą musiało być Pomorze, przeżywające w tym czasie dynamiczny rozwój gospodarczy. Oprócz srebra transportowano nim, poszukiwane przez zamożną część społeczności plemiennych, przedmioty luksusowe. 


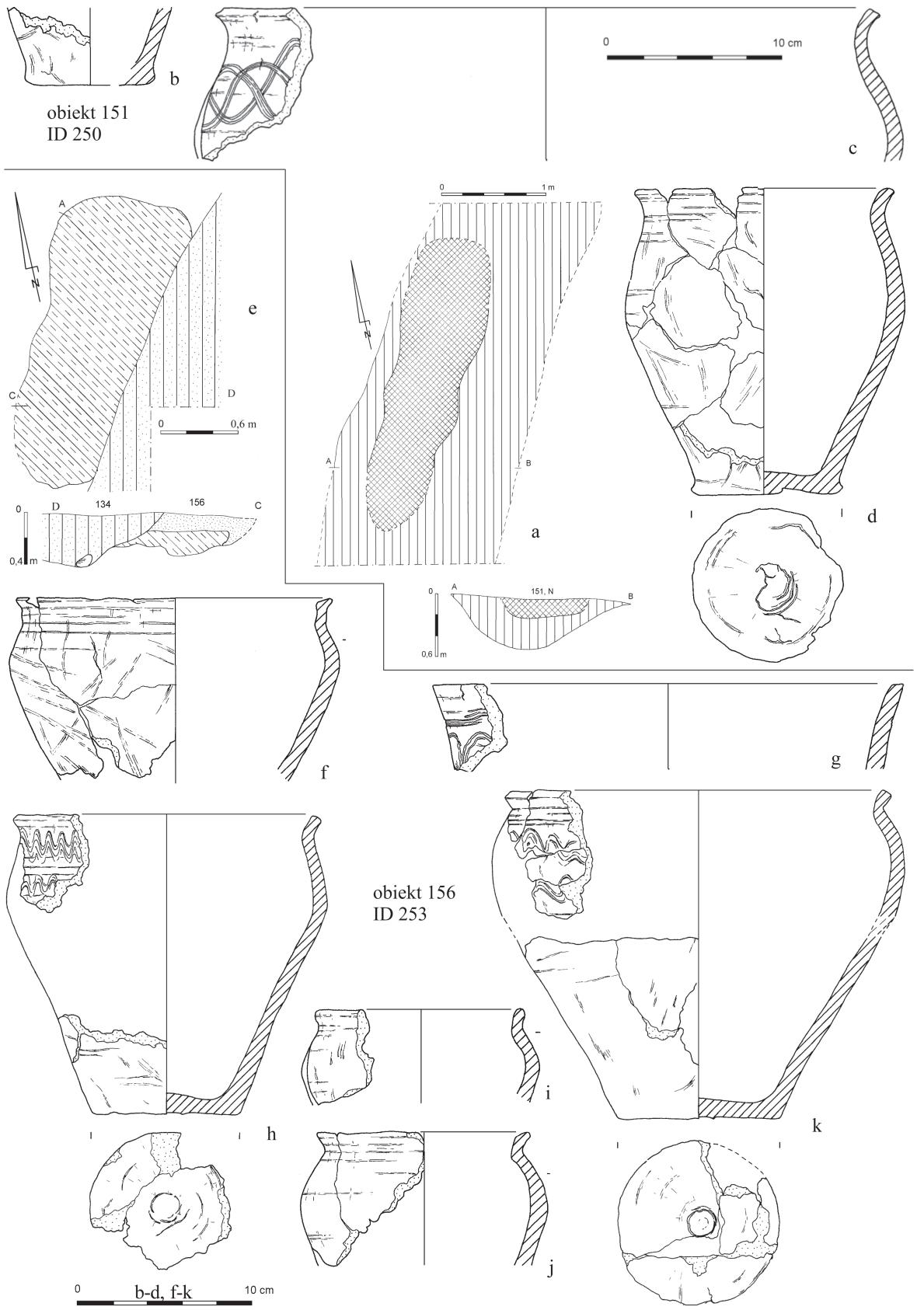

Ryc. 8. Napole, gm. Kowalewo Pomorskie, stanowisko 6. Wybór naczyń ceramicznych z obiektów 151 (a-d) i 156 (e-k) (rys. J. Bojarski, J. Weinkauf)

Fig. 8. Napole, Kowalewo Pomorskie commune, site 6. Selection of pottery vessels from features $151(\mathrm{a}-\mathrm{d})$ and $156(\mathrm{e}-\mathrm{k})$ (drawing by J. Bojarski, J. Weinkauf) 
Efektem dalszych zmian gospodarczych oraz przemian o charakterze społeczno-politycznym (konsolidacji i przejęcia kontroli oraz zysków z handlu), zachodzących we wspólnocie ostrowickiej, była przypadająca na 2. połowę X wieku budowa grodu. Jego wzniesienie wymagało podjęcia wielkiego wysiłku przez całą lokalną wspólnotę. Gród ten z czasem przekształcił się w siedzibę władzy plemiennej. Musiało się to zbiec $\mathrm{w}$ czasie $\mathrm{z}$ różnicowaniem społecznym mieszkańców zespołu osadniczego oraz zmianą charakteru i funkcji poszczególnych członów osiedli, a co za tym idzie zarysowania się opozycji gród-osiedle; podkreśleniem tego faktu było powstanie między grodem a położonym po jego zachodniej stronie osiedlem (stanowisko 6) kolejnego rowu (obiekt 23), biegnącego w poprzek osi pagórka. Powierzchnia tego osiedla nie uległa poszerzeniu, odnotowano natomiast zwiększenie gęstości zabudowy (większa liczba jam), skupionej na wypłaszczonej części pagórka. Na zachód od zwartej zabudowy mieszkalnej znajdowały się jamy wędzarskie i dziegciarskie. Zabudowa wewnątrz wałów grodowych miała charakter półziemiankowy; na jej ślady natrafiono w północno-wschodniej i wschodniej części majdanu. Być może obejmowała ona również pozostałe jego części, przykryte w kolejnych fazach rozbudowy grodu warstwami nasypowymi wału. Bardziej zwarty charakter miała także część użytkowa osiedla wschodniego, w obrębie której znajdowały się wyłącznie obiekty gospodarcze, między innymi duże kamienne piece. Prawdopodobnie ta część kompleksu osadniczego pełniła rolę zaplecza produkcyjnego, wykorzystywanego przez mieszkańców grodu.

Wraz ze wzrostem znaczenia miejscowej wspólnoty następował rozrost struktury osadniczej kontrolującej przebiegający w pobliżu szlak handlowy. W odległości około $2 \mathrm{~km}$ na południowy zachód od grodu, w niewielkiej dolince prowadzącej do przeprawy przez Drwęcę w okolicy Golubia, powstało nowe osiedle (Ostrowite, stanowisko 14). Kompleks osadniczy nad jeziorem Oszczywilk od 2. połowy $\mathrm{X}$ wieku pełnił funkcję czoła opolnego. Wiele wskazuje na to, że powierzchnia obszaru eksploatowanego przez mieszkańców mikroregionu obejmowała także teren położony po drugiej stronie Drwęcy (Chudziak 1996b, s. 180; tab. 37). Brak tam datowanego na wspomniany okres ośrodka osadniczego, który mógłby stanowić konkurencję dla mieszkańców Ostrowitego. Tego typu struktury, skupione wokół grodów w Nowogrodzie i Piotrkowie, datowane są na 1. połowę XI wieku i ich powstanie można wiązać z reorganizacją struktur osadniczych tego obszaru, przeprowadzoną przez Piastów. Z końcem X lub na początku XI wieku doszło do rozbicia struktur grodowych na całym obszarze ziemi chełmińskiej (Chudziak 1996b, s. 196; 1997b, s. 17 i nn.); zniszczeniu uległy obiekty położone nad dolną Drwęcą, również w Ostrowitem (ślady spalenizny na grodzisku). Wydarzenia te powszechnie wiąże się z rozbudową terytorialną państwa pierwszych Piastów, które rozpoczęło ekspansję w kierunku Morza Bałtyckiego i obszarów pruskich. Nowa władza zmierzała do dezintegracji starych struktur i budowy nowych, opartych na silnych warowniach podległych namiestnikom władcy polskiego (ryc. 7: C). 
Konsekwencją zmian w organizacji lokalnej sieci osadniczej było odbudowanie w krótkim czasie grodu, połączone z rozbudową wałów wzniesionych w technice przekładkowej. Podporządkowanie plemiennej sieci osadniczej władzy książęcej Piastów wymagało kontroli i sprawnej komunikacji, czemu służyło ponowne aktywowanie szlaków lądowych łączących centrum państwa z terenami nowo pozyskanymi (Chudziak 1997b, s. 19 i nn.). Na ten czas należałoby zapewne datować wzniesienie wału zaporowego od wschodu, chroniącego wjazd do wnętrza grodu ${ }^{7}$. Podkreśleniem militarnego charakteru całego kompleksu osadniczego było powstanie dwóch rowów, szerszych i głębszych niż wcześniejsze. Rów zamykający gród wraz z położonym od wschodu osiedlem (obiekt 20), uchwycono na długości $70 \mathrm{~m}$, miał szerokość $2,5 \mathrm{~m}$ i głębokość $1 \mathrm{~m}$. Drugi, usytuowany po zachodniej stronie grodu (obiekt 38), zadokumentowany na odcinku ponad $30 \mathrm{~m}$, miał szerokość $3 \mathrm{~m}$ i głębokość ponad $1 \mathrm{~m}$. Możliwe, że oba rowy po północnej stronie grodu łączyły się ze sobą tworząc jedną linię, półkoliście zamykającą gród wraz z przyległym od północy terenem. Powierzchnia obszaru ograniczonego rowem wynosiłaby według szacunkowych wyliczeń od 2 do 2,5 ha. Zmniejszeniu do 6 arów uległa zabudowa osiedla zachodniego. Dobrze poświadczone pozostałości zabudowy z tej fazy odsłonięto za to w obrębie grodziska. Były to zagłębione w ziemię budynki układające się koliście wokół pustego majdanu.

Na pierwsze trzy dziesięciolecia XI wieku przypadł czas pomyślnego rozwoju mikroregionu, którego prawdopodobnie nie przerwał kryzys monarchii piastowskiej, przypadający na lata 30. tego stulecia. Silne związki z Kujawami za pośrednictwem dolnego odcinka Drwęcy potwierdzają naczynia ceramiczne nawiązujące w swej formie i zdobnictwie do egzemplarzy wykonanych w stylu Gronowo II (ryc. 9) (Bojarski 2012, s. 249). Istotne znaczenie miało natomiast datowane na ten okres uniezależnienie się Mazowsza, zarządzanego przez Miecława, byłego cześnika Mieszka II, którego władza została rozszerzona także na ziemię chełmińską (Wyrozumski 1988, s. 96; Bieniak 2010). Stwierdzono jednak zmniejszenie się powierzchni zabudowy na osadzie zachodniej, której granicę wyznaczał nowy rów (obiekt 9), zamykający przestrzeń położoną bezpośrednio przy wałach grodu. Połączenia komunikacyjne, dobrze poświadczone archeologicznie dla 1. ćwierci XI wieku, wykorzystywane były także w okresie osłabienia państwa polskiego. Na przełom lat 40. i 50. XI wieku przypadało ponowne ożywienie kontaktów handlowych z Rusią za pośrednictwem starego szlaku, który z Chełmna prowadził po linii wyznaczonej przez grody w Lipienku, Ryńsku, Ostrowitem, przez przeprawę w Golubiu (domniemany gród?). Za Drwęcą szlak ten rozdzielał się na dwa odcinki, z których jeden kierował się na Drohiczyn, drugi zaś na Płock. Istnienie tego szlaku dobrze potwierdzają skarby srebrne ukryte po połowie XI wieku w Skrwilnie (po 1077 roku), Golubiu (po 1060 roku) czy Rychnowie

${ }^{7}$ Określenie chronologii tego wału ma wyłącznie charakter przypuszczenia, ponieważ nie prowadzono badań wykopaliskowych w tej części stanowiska. 

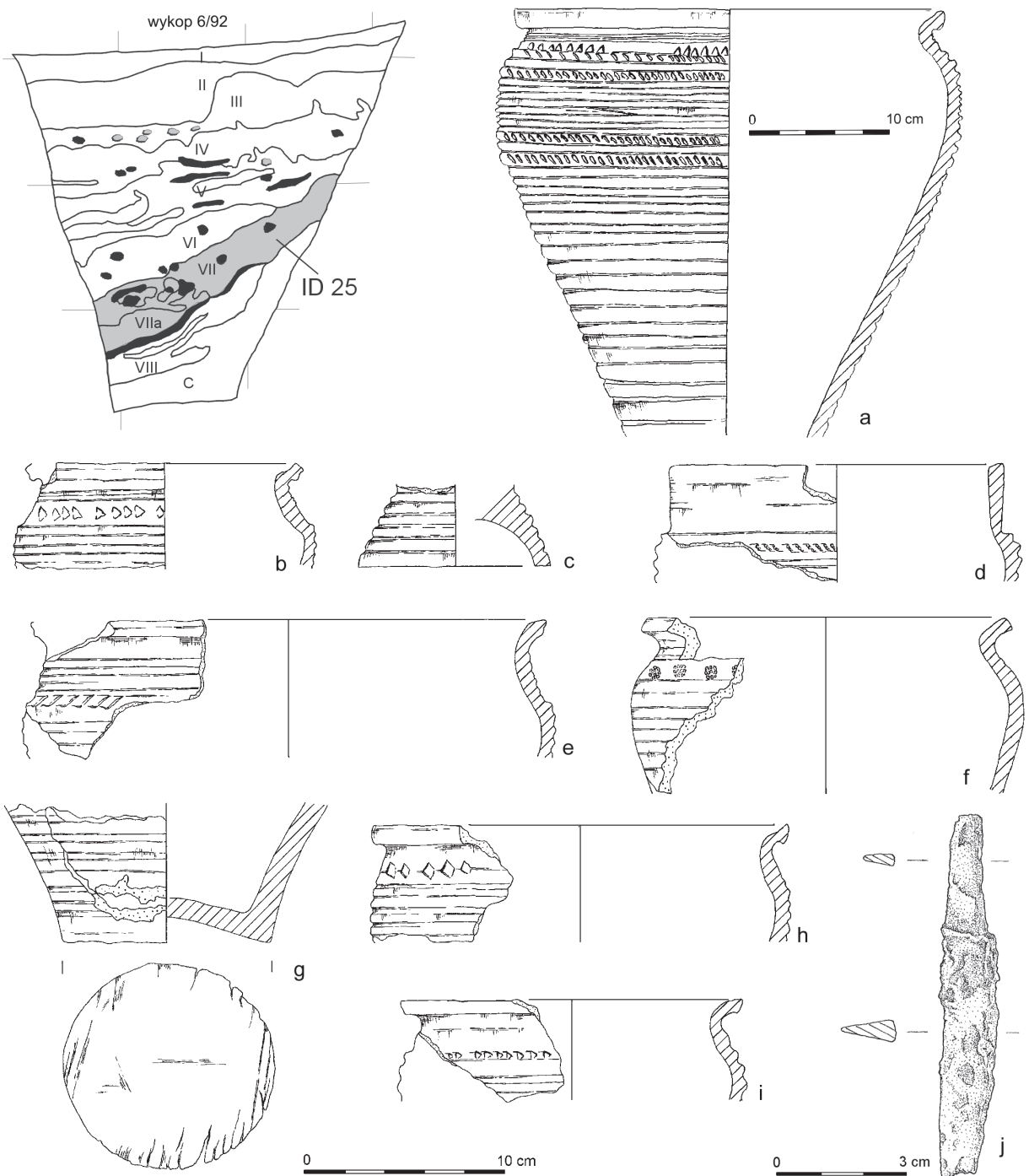

g
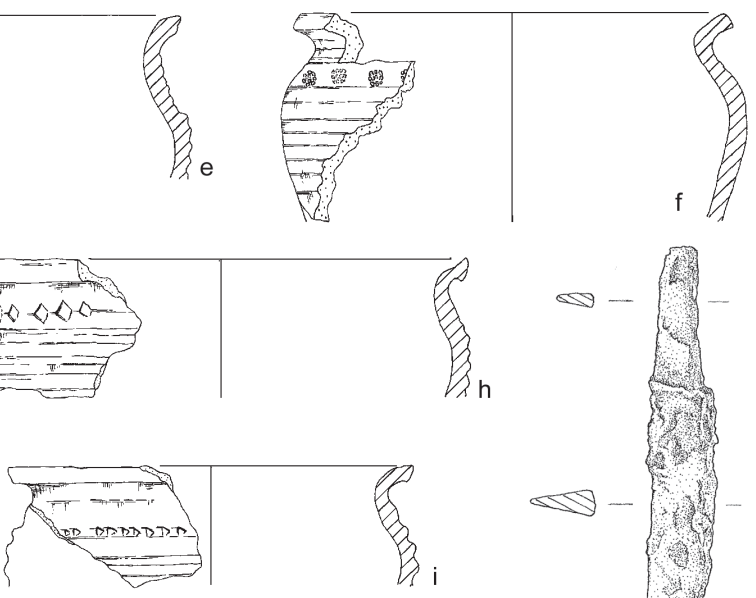

Ryc. 9. Napole, gm. Kowalewo Pomorskie, stanowisko 1. Wybór naczyń ceramicznych z wykopu VI/92, warstwy VII i VIIa (rys. J. Bojarski, H. Michel, J. Tarentowicz)

Fig. 9. Napole, Kowalewo Pomorskie commune, site 1. Selection of pottery vessels from trench VI/92, layers VII and VIIa (drawing by J. Bojarski, H. Michel, J. Tarentowicz)

(po 1042 roku) (Chudziak 1997a, s. 113 i nn.; Kowalewski 2003, s. 161). Z aktywną wymianą handlową prowadzoną w tym okresie można łączyć między innymi zdobioną szpilę z poroża w stylu Borre, znalezioną na terenie osady zachodniej, pochodzącą być może z pomorskich pracowni rogowiarskich (Duczko 2000, s. 29; 
Chudziak, Kaźmierczak 2013, s. 18; Stanisławski 2013, s. 38 i nn.) oraz zapinkę podkowiastą typu bałtyjskiego (Łukasiak 1999; Bojarski 2012, s. 260, ryc. 124).

Pod koniec XI stulecia doszło do kolejnej przebudowy grodu, na co wskazuje warstwa niwelacyjna zalegająca na reliktach zabudowy z połowy XI wieku. Rozmieszczenie budynków mieszkalnych zapewne stanowiło konsekwencję zmian politycznych i własnościowych, które miały miejsce w tym czasie. Ziemia chełmińska została administracyjnie podporządkowana Mazowszu, którego władcą zwierzchnim pozostawał książę Władysław I Herman. Obszar samej wspólnoty stał się, być może, częścią uposażenia biskupstwa płockiego, powołanego do życia około roku 1075 (Powierski 1973a, s. 57; Łowmiański 1985, s. 355 i nn.). W znacznym stopniu powiększył się obszar obwarowany, przywróconymi(?) do użytku rowami, w sumie do około 3-4 ha. Nie zmienił się natomiast charakter obu osiedli położonych na zewnątrz wałów, traktowanych jako zaplecze gospodarczo-produkcyjne. W końcu XI lub na początku XII wieku na zachód od grodu, w miejscu, gdzie wcześniej znajdowało się osiedle, powstał cmentarz. Warto zwrócić uwagę, że jamy grobowe występowały wyłącznie między dawnymi rowami (obiektami 134 i 23), które do połowy XI wieku ograniczały główną część zabudowy mieszkalnej osiedla. Być może rowy te były w tym czasie wciąż czytelne w terenie ${ }^{8}$. Prawdopodobnie na cmentarzu chowano mieszkańców grodu, o czym może świadczyć niewielka liczba zmarłych (24 groby), a także duży udział pochówków wyposażonych (niemal 60\%), wskazujących z jednej strony na znaczny tradycjonalizm, z drugiej zaś na stosunkowo wysoki status społeczny zmarłych. Potwierdzeniem tego ostatniego może być zwłaszcza grób nr 13 (Stawska 2003, s. 100; Bojarski 2014, s. 180), nawiązujący pod względem wielkości i konstrukcji do grobów komorowych znanych z Kałdusa (Chudziak 2001; Bojarski 2005, s. 112-114; 2007, s. 269-271; Bojarski i in. w druku) oraz Pnia na ziemi chełmińskiej (Drozd, Janowski, Poliński 2009; 2011; Janowski 2010), w których chowano członków elity społecznej. Do tej grupy należą również grób mężczyzny z grotem włóczni (nr 7), grób dziecięcy (nr 14) z bogatym zestawem ozdób (między innymi osiem fragmentów kaptorg z brązu), a także grób nr 21 z kompletem brązowych sprzączek, ogniwek i okuć pasa (ryc. 10) (Bojarski 2014, s. 176 i nn.).

W XII wieku powierzchnia bezpośrednio objęta zabudową uległa ponownej redukcji. Prawdopodobnie zmienił się także sposób użytkowania terenu przylegającego do grodu od wschodu. Być może doszło do przesunięcia zabudowy na jego północną stronę, niestety, w tym miejscu nie prowadzono rozpoznania archeologicznego. Wraz z zanikiem zabudowy na osiedlach podgrodowych straciły na znaczeniu także rowy otaczające gród. Pozostałości zabudowy mieszkalnej odsłonięte zostały tylko w południowo-wschodniej części majdanu grodziska

${ }^{8}$ Mogłoby na to wskazywać odkrycie w zasypisku rowu (ob. 23) pojedynczych kości ludzkich, pochodzących zapewne ze zniszczonych w późniejszym czasie jam grobowych. 


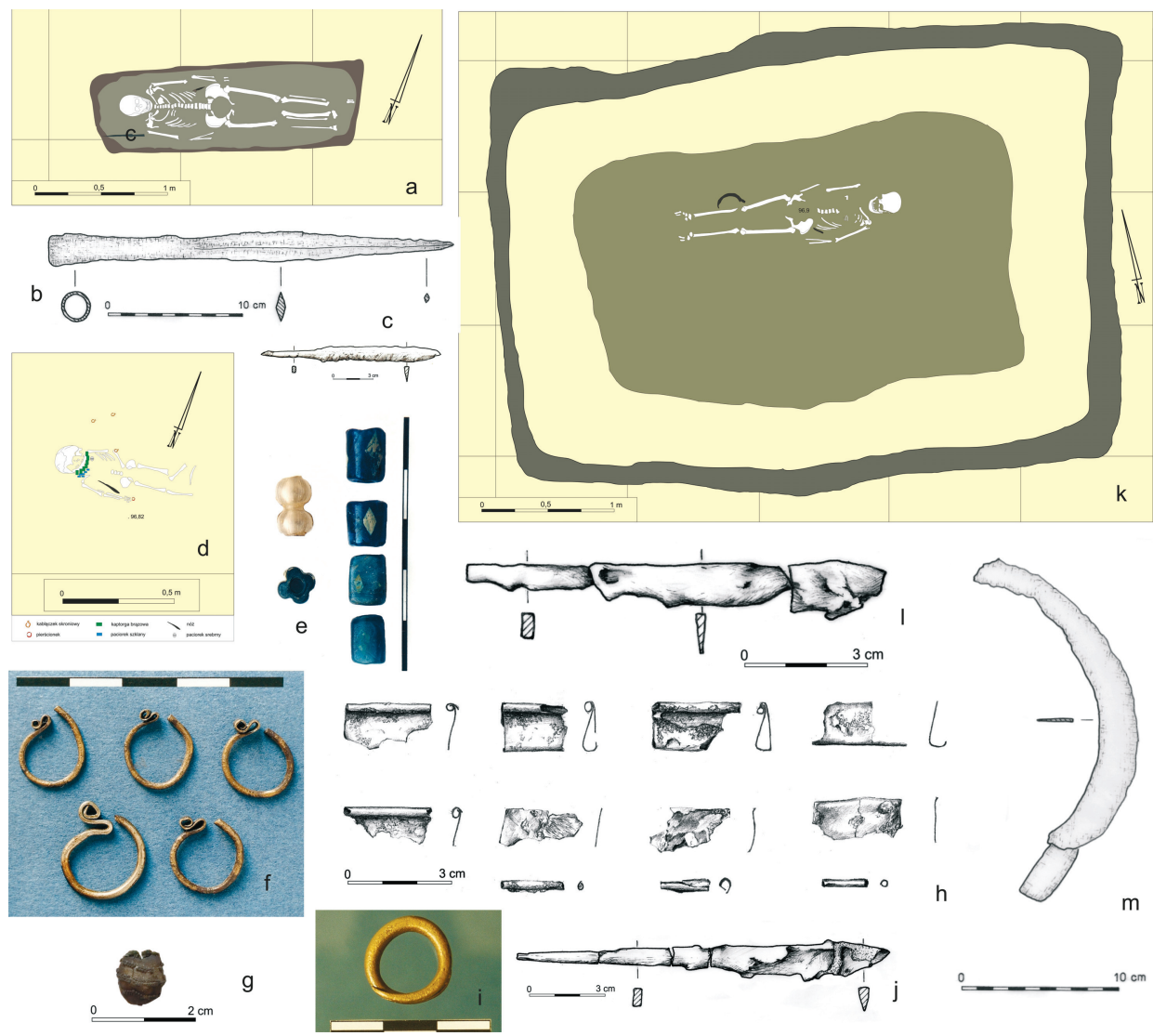

Ryc. 10. Napole, gm. Kowalewo Pomorskie, stanowisko 6. Wybrane groby wraz z wyposażeniem: a-c - grób 7, d-j - grób 14, k-m - grób 13 (rys. J. Bojarski, D. Klajbor, M. Wachnik)

Fig. 10. Napole, Kowalewo Pomorskie commune, site 6. Selected graves with furnishing: a-c - grave 7, d-j - grave 14, k-m - grave 13 (drawing by J. Bojarski, D. Klajbor, M. Wachnik)

(trzeci poziom), w pobliżu bramy. Zapewne zmieniła się rola grodu wpisanego w administracyjną sieć Mazowsza, podporządkowaną nowemu podziałowi ziemi chełmińskiej i północnej części ziemi dobrzyńskiej na trzy kasztelanie z grodami centralnymi w Chełmnie, Steklinie i Rypinie (Powierski 1973a, s. 9, mapa; Chudziak 1996b, s. 196 i nn., ryc. 6) (ryc. 7: D). Dobra ostrowicko/napolsko-golubskie, znane z późniejszych źródeł, podlegałyby administracyjnie kasztelani steklińskiej (Powierski 1973b). W opisywanym okresie wykorzystywany był szlak komunikacyjny łączący ziemię chełmińską z Rusią. Stamtąd zostały sprowadzone przęśliki z różowego łupku, cylindryczna kłódka, szklane paciorki czy niektóre ozdoby ciała 
i części stroju (np. brązowa sprzączka lirowata), znalezione na osadzie, w grobach lub na grodzisku. Te ostatnie przedmioty wskazują na silne związki kulturowe z dzielnicą mazowiecką. Najlepszym przykładem trwałych kontaktów są między innymi naczynia ceramiczne nawiązujące pod względem formy i stylistyki do egzemplarzy znanych z Czerska, Płocka i Drohiczyna (ryc. 11; Bojarski 2012, s. 273 i nn.). Analiza zasiedlenia południowo-wschodniej części ziemi chełmińskiej potwierdza łączność osadnictwa na obu brzegach Drwęcy w ciągu całego XII wieku (Chudziak 1996b, ryc. 6). Stan ten uległ radykalnej zmianie na początku XIII stulecia, gdy na ziemię chełmińską najechali Prusowie. Spustoszeniu uległy wówczas położone nad jeziorem Oszczywilk dobra kompleksu napolskiego, zniszczony został również gród. W czasie, gdy ziemia chełmińska na mocy tzw. przywileju z Lonyz przekazana została przez Konrada Mazowieckiego biskupowi pruskiemu Chrystianowi, gród w Ostrowitem pozostawał prawdopodobnie niezamieszkany. Tym można tłumaczyć użycie w treści dokumentu określenia quondam castrum odnoszącego się do stanu faktycznego (PrU, t. 1/1, nr 41). Trudno jednak przypuszczać, że wyludnieniu uległ cały kompleks osadniczy wraz z przyległymi osiedlami. Prawdopodobnie treść dokumentu informowała jedynie o utracie przez władcę Mazowsza kontroli nad dawnymi centrami administracyjnymi. Ponowne zasiedlenie grodu nastąpiło prawdopodobnie po roku 1235, kiedy Krzyżacy zwrócili za rekompensatę pieniężną dobra ostrowickie biskupstwu włocławskiemu (Powierski 1973a, s. 58).

W tym momencie musimy cofnąć się do ostatniej ćwierci XII wieku, aby wyjaśnić kwestie prawno-własnościowe opisywanych dóbr. Prawdopodobnie wczesnopiastowski jednolity system grodowo-terytorialny związany z organizacją mazowieckiej prowincji uległ z końcem XII wieku rozkładowi. Zmieniające się stosunki feudalne, postępujące rozbicie dzielnicowe i obejmujące coraz szersze dziedziny przemiany życia społeczno-politycznego, doprowadziły do zmian własnościowych w obrębie dotychczasowych dóbr książęcych. Mimo obowiązującego regale książęcego na budowę i posiadanie warowni przywilej ich posiadania rozciągnięty został stopniowo na włości biskupie i katedralne (Kołodziejski 1992, s. 278). Nie wiadomo dokładnie kiedy i w jakich okolicznościach dobra ostrowickie przeszły w ręce powstałego z wyłączenia z diecezji płockiej biskupstwa włocławskiego. Być może stało się to równocześnie z nadaniem w 1185 roku biskupstwu rozległych terytoriów kasztelanii słońskiej (Powierski 1977, s. 36). Natomiast nie poparta żadnymi źródłami pisanymi - poza pośrednimi i w tym przypadku mocno dyskusyjnymi argumentami wyprowadzonymi z analizy źródeł pisanych i danych archeologicznych - jest jeszcze wcześniejsza przynależność tego terenu do uposażenia biskupstwa płockiego, powstałego w latach 70. XI wieku. Być może dotyczyło to terenów położonych na wschód i północ od Ostrowitego, czyli okolic Kowalewa i Lisewa, które według Jana Powierskiego taką zależność wykazywały również w późniejszym okresie. Na dawną przynależność klucza 

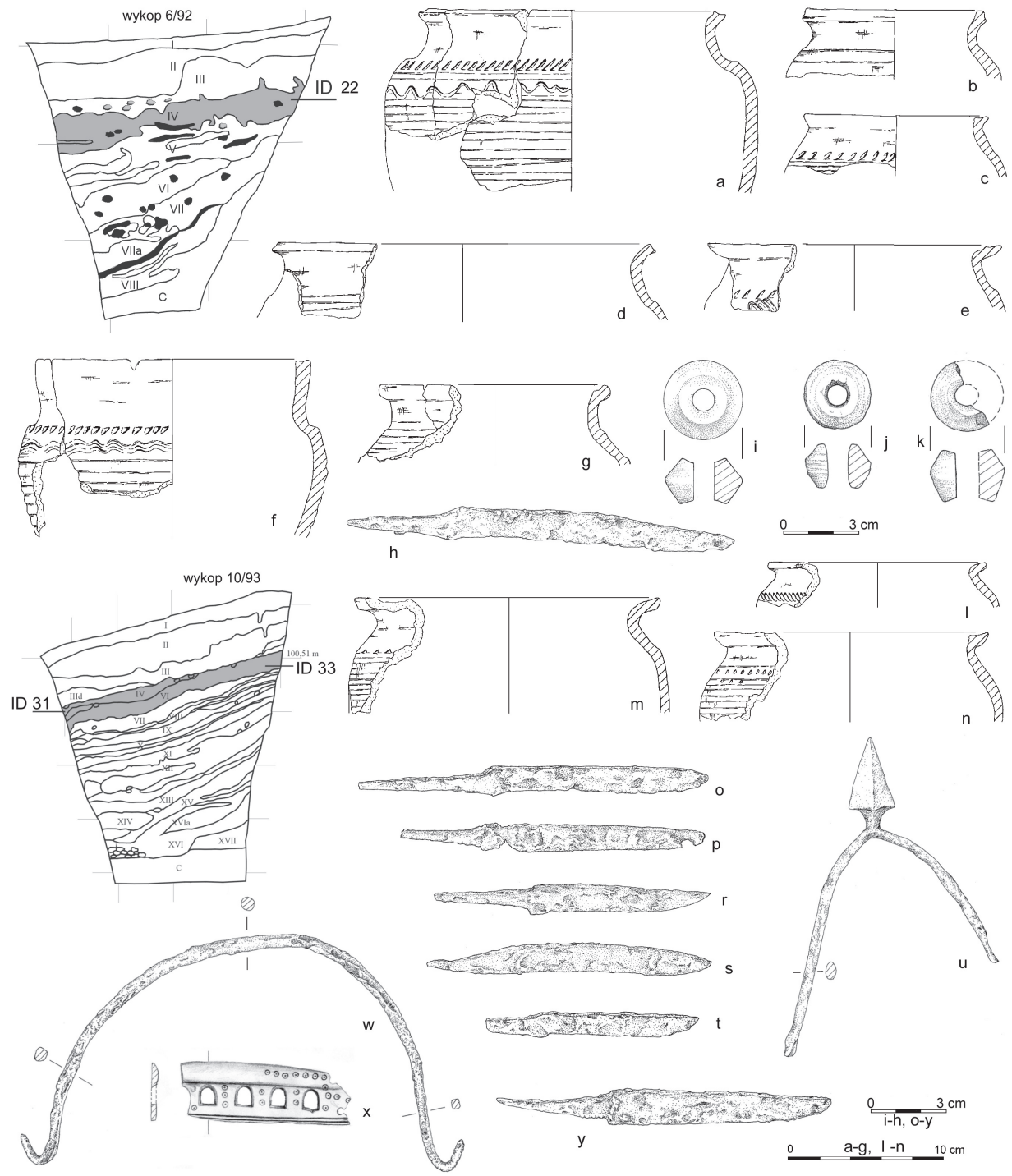

Ryc. 11. Napole, gm. Kowalewo Pomorskie, stanowisko 1. Wybór naczyń ceramicznych (a-g, l-n), przęślików ceramicznych (i-1), przedmiotów żelaznych (h, o-w, y), okładzin kościanych (x) (a-i-wykop 6/92, warstwa IV; j-s. u - wykop 10/93, warstwa IV; t-w, y- wykop 10/93, warstwa VI) (rys. J. Bojarski, M. Lenk, H. Michel, M. Wachnik, J. Weinkauf)

Fig. 11. Napole, Kowalewo Pomorskie commune, site 1. Selection of pottery vessels $(\mathrm{a}-\mathrm{g}, \mathrm{l}-\mathrm{n})$, clay spindle whorls $(\mathrm{i}-\mathrm{l})$, iron artefacts $(\mathrm{h}, \mathrm{o}-\mathrm{w}, \mathrm{y})$, bone mounts $(\mathrm{x})$ (a-i - trench 6/92, layer IV; j-s. u - trench 10/93, layer IV; t w, y - trench 10/93, layer VI) (drawing by J. Bojarski, M. Lenk, H. Michel, M. Wachnik, J. Weinkauf) 
ostrowickiego do posiadłości biskupstwa włocławskiego powołano się w dokumencie wystawionym przez Kazimierza kujawskiego dla tego biskupstwa, w którym uzyskało ono potwierdzenie swych praw do dóbr położonych za Wisłą, na terenie ziemi chełmińskiej, poprzez podkreślenie, że chodzi o „dawne wsie”, posiadane przez biskupstwo włocławskie. Janusz Bieniak uważał, że biskupstwo miało $-a b$ antiquo - tylko Pluskowęsy, Złotorię i zaginiony Mukowar, zgodnie z tekstem dokumentu krzyżackiego z 1258 roku (Bieniak 1970, s. 28). O zwartości i jednolitości tego terytorium, jako klucza stanowiącego własność jednej instytucji, w tym przypadku biskupstwa, świadczy brak innych, poza krzyżackimi, posiadłości po jego przekazaniu w 1293 roku.

Nasilone najazdy pruskie w początku XIII wieku, a szczególnie niszczący najazd z 1217 roku, przyczyniły się do spustoszenia ziemi chełmińskiej i zapewne dóbr biskupich skupionych wokół Ostrowitego. W 1223 roku biskup płocki Gunter zrzekł się swoich posiadłości w ziemi chełmińskiej na rzecz Chrystiana, nic jednak nie wiadomo o zrzeczeniu się prawa do swoich włości przez biskupa włocławskiego. Przywołany tu już wcześniej dokument preceptora krzyżackiego w Prusach, Gerharda von Hirschberg, stwierdza, że Herman Balk już w 1230 roku (historycy uważają, że raczej chodzi o rok 1235, kiedy Krzyżacy uzyskali po układach z księciem Konradem prawo do wschodniej części ziemi chełmińskiej, z wyłączeniem dóbr ostrowickich) zwrócił biskupstwu majątki Pluskowęsy, Mukowar i Złotorię. Z uwagi na peryferyjne położenie tych włości w stosunku do centralnego grodu w Ostrowitem można przyjąć, że zwrot dotyczył całości tego terenu, a wymieniono jedynie miejscowości graniczne, zgodnie z praktyką kancelaryjną opisu. $Z$ dokumentu tego wynika również, że zarówno włość Pluskowęsy, jak i Mukowar zostały odstąpione Zakonowi, zapewne jako rekompensata, ponadto biskupstwo włocławskie zobowiązywało się do opłacania daniny z posiadanych dóbr w postaci wystawienia pięciu zbrojnych, 10 grzywien wosku i pięciu denarów kolońskich srebrem (Powierski 1977, s. 50 i nn.). Obciążenia te były typowe dla posiadłości liczących pięć wsi, a więc tyle powinno być ich w granicach klucza ostrowickiego. W 1245 roku biskupstwo powiększyło swój stan posiadania przez zakup wsi Krążno (między Pluskowęsami a Ciechocinem) z Lasem Mokrym, które stanowiły, być może, kolejną część dóbr utraconych przez biskupstwo w wyniku najazdów pruskich w początku XIII wieku, a pomiędzy 1246 a 1252 rokiem za 100 grzywien srebra - Ostrowite, zaginione Usansewo i Chełmonie. Dodatkowo w 1254 roku biskup Wolimir nabył wieś Golub. Jan Powierski akt zakupu Golubia uznał za okres zamykający restytucje utraconych dóbr biskupich na terenie ostrowicko-golubskim (Powierski 1977, s. 56 i nn.). Potwierdzeniem tego był wspomniany już dokument z 1258 roku. Zastanawiać może brak wzmianki w tym dokumencie o grodzie w Ostrowitem i Chełmoniu oraz Golubiu. W przypadku Golubia archeologicznie potwierdzono tylko pozostałości rozległej osady, datowanej na XI-XII wiek, natomiast w pozostałych dwóch miejscowościach być może grody 


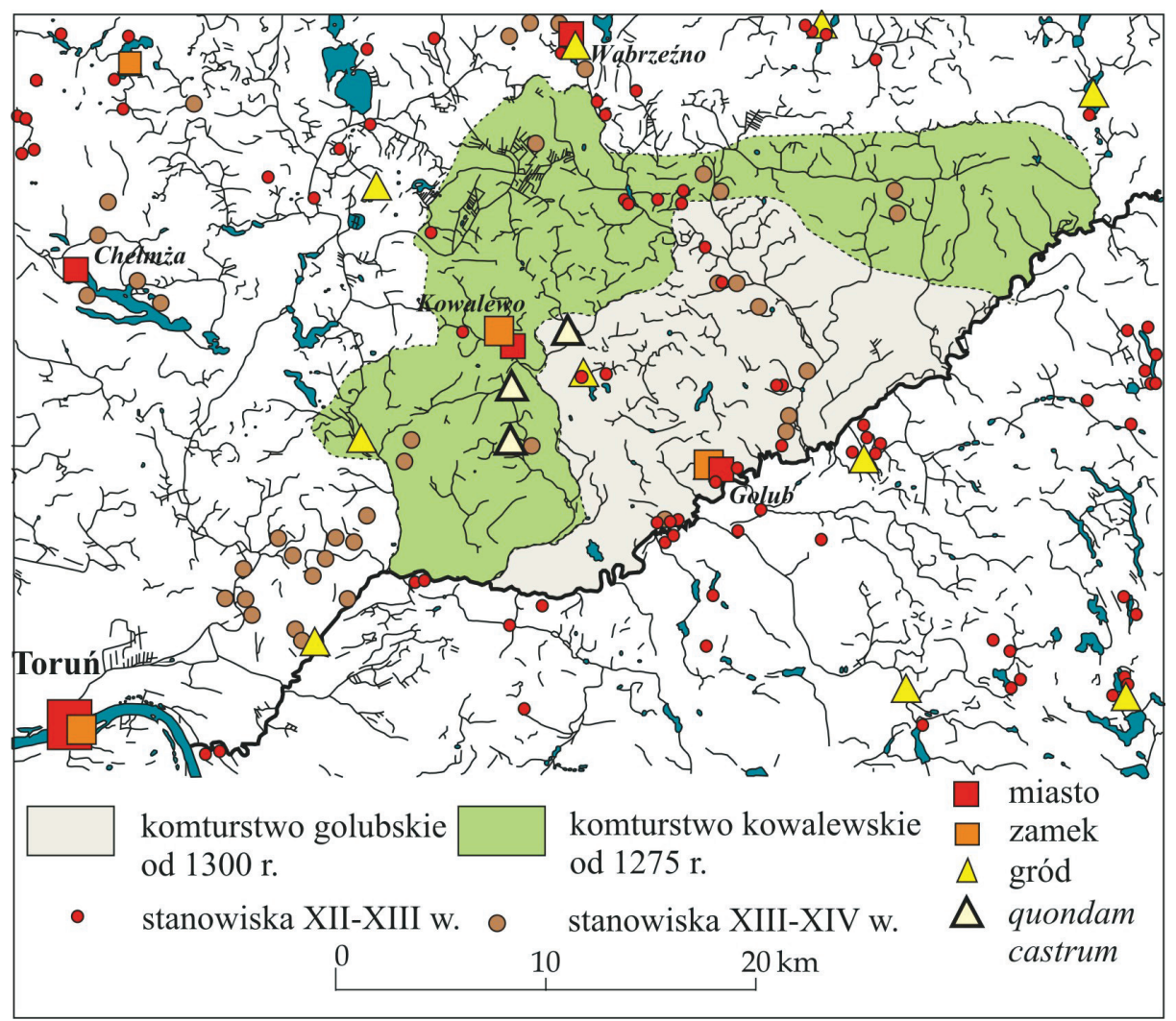

Ryc. 12. Zasiedlenie dorzecza dolnej Drwęcy w 2. ćwierci XIII-XIV wieku z zasięgiem granic komturstwa kowalewskiego i golubskiego (wg Poliński 2001; 2003; rys. J. Bojarski)

Fig. 12. Settlement of the lower Drwęca River basin in the second quarter of the $13^{\text {th }}-14^{\text {th }}$ century, with range of borders of Kowalewo and Golub commandry (after Poliński 2001; 2003; drawing by J. Bojarski)

nie były zamieszkane. Nie sprzyjały stabilizacji osadniczej kolejne najazdy pruskie i litewskie przypadające na lata 1260-1273. Zwłaszcza wyprawa Skomanda mogła dosięgnąć dóbr ostrowickich (Powierski 1977, s. 81; Piotr z Dusburga 2004, s. 136 i nn.). Zabezpieczeniu posiadłości krzyżackich miało służyć wzmocnienie załogi w Kowalewie oraz budowa zamku i lokacja miasta w 1275 roku. Był to pierwszy krok do przejęcia włości ostrowickich i oparcia granicy państwa krzyżackiego o Drwęcę w celu zabezpieczenia przeprawy w Golubiu. Również biskupstwo włocławskie starało się zorganizować na nowo dobra ostrowickie. W związku z tym w 1276 roku nastąpiło nadanie w dzierżawę ,z dawna opuszczone i nie uprawiane dobra [...] ostrowicko-golubskie" w całości, dwóm rycerzom spod Oleśnicy - Szymonowi Gallikowi i Wojciechowi ze Stwolna (Smolna), którzy 
mieli rozpocząć nowy etap kolonizacji tego obszaru i jego reorganizację. Za dobra te mieli zapłacić czynsz od połowy posiadłości, ale dopiero po 15 latach wolnizny (PrU, t. 1/2, nr 349) ${ }^{9}$. Obciążenia na rzecz biskupstwa były identyczne jak te, które ponosiło z tych dóbr biskupstwo na rzecz zakonu krzyżackiego. Według dokumentu wystawionego przez biskupa Albierza przekazano dobra o powierzchni 1000 łanów, tj. około $168 \mathrm{~km}^{2}$. W obszar ten oprócz dóbr ostrowickich wchodziła częściowo Złotoria; w granicach tego nadania znalazły się wymienione z nazwy wsie: Ostrowite, Golub, Pluskowęsy, Krążno, Chełmionie z Chełmońcem i wiele innych, położonych po prawej stronie Drwęcy, a więc obszar mieszczący się w trójkącie, którego wierzchołkami były Pluskowęsy, Chełmonie na zachodzie i Golub na południu. Terytorium to na południu opierało się o tereny podmokłe i leśne zaliczane do tzw. Lasu Mokre ${ }^{10}$. Prawdopodobnie nie do końca udało się rozwinąć akcję kolonizacyjną w dobrach ostrowickich, skoro w wyniku skarg krzyżackich na niewywiązywanie się z wcześniejszych umów z 1258 roku oraz procesów sądowych, doszło do kolejnej ugody między biskupstwem włocławskim a Zakonem. W jej wyniku 18 kwietnia 1293 roku biskup włocławski Wisław ostatecznie zrzekł się włości położonych przy Ostrowitem i Golubiu. Z dokumentu tego wynika, że obie miejscowości miały już ten sam status prawny (Powierski 1977, s. 152). Ugoda ta została zawarta w Ostrowitem rok wcześniej, stanowiącym aż do tego momentu miejsce zarządzania posiadłościami tego klucza (PrU, t. 1/1, nr 606). Wojciech ze Stwolna miał dobra ostrowicko-golubskie posiadać dalej z obowiązkiem spłaty należnego czynszu rekognicyjnego i dostarczania pięciu służb w zbroi ciężkiej na rzecz Krzyżaków, a więc na takich samych warunkach, na których także biskupstwo posiadało te dobra. Już w 1299 roku całe dobra ostrowickie przeszły w zarząd komturstwa golubskiego (po śmierci Wojciecha?). Zbiegło się to w czasie z kolejnym najazdem Litwinów na te tereny, w wyniku których, jak podaje Piotr z Dusburga, zniszczone i spalone zostały gród w Golubiu i pięć okolicznych wsi (Piotr z Dusburga 2004, s. 190, nr 268). W tym okresie zaczęło wzrastać znaczenie Golubia, jako ośrodka leżącego bezpośrednio przy przeprawie przez Drwęcę, na skrzyżowaniu szlaków, a przede wszystkim w miejscu ważnym strategicznie (ryc. 12). To zdecydowało, że po zajęciu klucza ostrowickiego Krzyżacy przystąpili do budowy w Golubiu konwentu, którego siedzibą stał się murowany zamek, a u stóp wzgórza zamkowego ulokowali po

\footnotetext{
${ }^{9} \mathrm{Na}$ mocy dokumentu z 28 kwietnia 1276 roku biskup Albierz nadał Szymonowi Gallikowi i Wojciechowi ze Stwolna „Ostrowite, Golub, Pluskowęsy, Krążno, dwa Chełmonie (z Chełmońcem) i całą ziemię tych i innych wsi, położonych z tamtej strony Drwęcy, z rzekami lasami, jeziorami, gajami, borami, łowiskami i rybołówstwem i wszystkimi innymi użytkami jakiegokolwiek miana, które tam są lub mogłyby być posiadane" (Powierski 1977, s. 131).

${ }^{10}$ Według wyliczeń przeprowadzonych przez J. Powierskiego na podstawie szacowanej powierzchni wsi i majątków wchodzących w skład nadań uzyskanych przez obu rycerzy łączna powierzchnia tego obszaru była bliska $168 \mathrm{~km}^{2}$, a więc zgadzałaby się z zapisaną w dokumencie powierzchnią 1000 łanów (chełmińskich) (Powierski 1977, s. 108 i nn.).
} 
roku 1300 miasto (Powierski 1977, s. 164) ${ }^{11}$. Niemniej jeszcze w pierwszych latach XIV wieku kapelanem komturstwa golubskiego był pleban z Ostrowitego. Niestety, żadne źródło nie podaje informacji na temat parafii i kościoła we wsi, chociaż $\mathrm{z}$ racji przynależności tego obszaru do biskupstwa włocławskiego należałoby się takiego spodziewać. Ze źródeł pisanych wiemy, że w 1316 roku istniała w Ostrowitem karczma, jatka i ława sądowa, ale to dotyczyło już najprawdopodobniej nowo lokowanej wsi na miejscu dziś istniejącej (PrU, t. 2, nr 143, 148). Ostrowite założone zapewne przez Szymona Gallika stało się czynszową wsią krzyżacką z niewielkim działem własnościowym zwanym Małym Ostrowitem, z czasem przekształconym w majątek szlachecki. Dawny gród, jako wydzielona posiadłość rycerska ${ }^{12}$, być może wciąż zasiedlony, funkcjonował jeszcze na początku XV wieku (Biskup 1957, s. 40; Kola 1991, s. 184 i nn.).

\section{WNIOSKI}

Wykształcenie się silnych struktur osadniczych nad jeziorem Oszczywilk przypadło na czas rozpadu wspólnoty o charakterze mezoregionalnym, położonej nad Strugą Rychnowską, wokół pełniącego centralną pozycję grodu w Gronowie. O jej dynamicznym rozwoju w równym stopniu decydowało korzystne położenie - duże płaty żyznych gleb otoczone mało urodzajnymi sandrami i glebami bielicowymi, porośniętymi szerokimi pasami lasów, stanowiącymi naturalne bariery osadnicze, a także uwarunkowania komunikacyjne, w tym bliskość Drwęcy. Rzeka ta od samego początku wczesnego średniowiecza stanowiła swoisty „pas transmisyjny”, wzdłuż którego przemieszczała się ludność zasiedlająca tereny na obu jej brzegach. Ośrodek osadniczy w okolicy dzisiejszego Napola/Ostrowitego odgrywał niebagatelną rolę w wymianie prowadzonej na linii wschód-zachód oraz północ-południe. Sprzyjało temu dogodne położenie przy naturalnym ciągu arterii wodnych, dochodzących bezpośrednio do Drwęcy (Struga Młyńska i Ruziec, spinające ziemię dobrzyńską i chełmińską) oraz ułatwiających połączenie z centralną częścią ziemi chełmińskiej - z grodami w Ryńsku, Chełmży czy Wieldządzu. Ponadto istniało bezpośrednie połączenie wzdłuż bocznej dolinki erozyjnej z zespołem osadniczym w Gronowie, położonym na południowy zachód od Napola. Granice późniejszego centrum ostrowicko-golubskiego wyraźnie wyodrębniają się na tle mapy osadniczej południowo-wschodniej części ziemi chełmińskiej i przyległej północnej części ziemi dobrzyńskiej. Czytelne centrum złożone najpierw z dużej osady, a następnie z grodu i związanych z nim osiedli, tworzących właściwe jądro wspólnoty typu mikroregionalnego, otoczone było w różnych okresach położonymi

${ }^{11}$ Dokładna data budowy zamku oraz lokacji miasta nie jest znana.

12 Prawdopodobnie do końca XIV wieku Ostrowite (gród wraz z przyległymi wsiami) stanowił wyłączną własność zakonu krzyżackiego, z tego przed 1407 rokiem wyłączono włość rycerską. Gród (castrum) po raz ostatni wzmiankowany jest w 1347 roku (PrU, t. 4, nr 156). 
między centrum a peryferiami kilkunastoma (od 13 do 20) punktami osadniczymi. W czasach plemiennych tworzyły one związek terytorialny typu opolnego, a w młodszych fazach wczesnego średniowiecza okręg grodowy w systemie administracji państwa piastowskiego. Powierzchnia tej jednostki, znanej z późniejszych źródeł pisanych własności biskupstwa włocławskiego, nazwanej przez J. Powierskiego kluczem ostrowicko-golubskim, wynosiła około $140-160 \mathrm{~km}^{2}$, co pokrywa się z wielkością 1000 łanów, podaną w dokumencie z 1276. Obszar wchodzący w obręb grodu i osad wraz z polami wynosiłby około 60 łanów, jak wynikałoby z dużo późniejszych relacji odnoszących się do wielkości wsi Ostrowite (Powierski 1977, s. 109). Granice włości ostrowickich, a jednocześnie terytorium najintensywniej eksploatowane przez tę wspólnotę, wyznaczają bardzo wyraźnie pustki osadnicze widoczne w odległości 4-6 km od centrum, znajdującego się nad jeziorem Oszczywilk, oraz pas lasów - zachowanych jeszcze dziś wzdłuż doliny Drwęcy i Strugi Rychnowskiej. Dodatkowo granice jego w sposób symboliczny wyznaczają miejsca ukrycia skarbów, które jak się ostatnio uważa, deponowano na terenach pogranicznych; tak właśnie depozyty monet znalezione w Golubiu, Kowalewie, Rychnowie wpasowują się w strefy rozdzielające sąsiednie jednostki osadnicze. Kres tej strukturze przyniosło powstanie na jej krańcach dwóch centrów wojskowo-administracyjnych państwa zakonnego w Kowalewie i Golubiu, które przejęły funkcje dotychczasowego grodu w Ostrowitem.

\section{Bibliografia}

\section{Źródla pisane}

PrU - Preussisches Urkundenbuch, t. 1, oprac. R. Philipi, A. Seraphin, Königsberg-Marburg 1882; t. 2, oprac. M. Hein, E. Maschke, Königsberg 1939; t. 4, oprac. H. Köppen, Marburg 1960.

Literatura

Wykaz skrótów

AHP - Archaeologia Historica Polona, Toruń

Bieniak J.

1970 Studia nad dziejami ziemi chetmińskiej wokresie piastowskim, Rocznik Grudziądzki, t. 5-6, s. 5-69.

2010 Państwo Miecława, wyd. 2, Warszawa. 
Biskup M.

1957 Rozmieszczenie własności ziemskiej województwa chetmińskiego i malborskiego $w$ drugiej połowie XVI w., Toruń.

Bojarski J.

2005 Sprawozdanie z badań wczesnośredniowiecznego cmentarzyska szkieletowego w Katdusie koło Chetmna (stanowisko 4). Badania 2002-2003 rok, [w:] XIV Sesja Pomorzoznawcza, t. 2: Od wczesnego średniowiecza do czasów nowożytnych, red. H. Paner, M. Fudziński, Gdańsk 2005, s. 103-118.

2007 Sprawozdanie z badań prowadzonych na wczesnośredniowiecznym cmentarzysku szkieletowym $w$ Kałdusie koło Chetmna (stanowisko 4) w latach 2003-2005. Wstepne wyniki badań, [w:] XV Sesja Pomorzoznawcza, red. G. Nawrolska, Elbląg 2007, s. 263-274.

2012 Wczesnośredniowieczny mikroregion osadniczy na ziemi chetmińskiej. Wytwórczość garncarska jako źródło poznania lokalnych procesów osadniczych, Torun.

2014 Atrybuty władzy na przykładzie grobów z wczesnośredniowiecznego cmentarzyska w Napolu, woj. kujawsko-pomorskie, [w:] Królowie i biskupi, rycerze i chłopi - identyfikacja zmartych, Funeralia Lednickie. Spotkania 16, red. W. Dzieduszycki, J. Wrzesiński, Poznań, s. 173-186.

Bojarski J., Chudziak W., Kozłowski T., Reitsema L. J.

w druku Wczesnośredniowieczne groby komorowe z ziemi chełmińskiej, Światowid. Bojarski J., Gurtowski P.

1994 Wyniki badań weryfikacyjnych grodzisk wczesnośredniowiecznych ziemi chetmińskiej, [w:] Wczesnośredniowieczne grodziska ziemi chetmińskiej. Katalog źródet, red. J. Chudziakowa, Toruń, s. 11-15.

Bojarski J., Łukasiak J.

1993 Komunikat z badań wczesnośredniowiecznej osady w Napolu, gm. Kowalewo Pomorskie, stan. 6, [w:] Badania archeologiczne ośrodka toruńskiego w latach 1989-1992, red. J. Chudziakowa, Toruń, s. 133-137.

Chudziak W.

1993 Z badań nad wczesnośredniowiecznymi zespołami osadniczymi w Napolu, gm. Kowalewo Pomorskie i Gronowie, gm. Lubicz w woj. toruńskim, [w:] Badania archeologiczne ośrodka toruńskiego w latach 1989-1992, red. J. Chudziakowa, Toruń, s. 119-128.

1996a Quondam castra wświetle badań wczesnośredniowiecznych grodzisk ziemi chetminskiej, AHP, t. 3, s. 25-34.

1996b Zasiedlenie strefy chetmińsko-dobrzyńskiej we wczesnym średniowieczu (VII-XI w.), Toruń.

1997a Dalekosiężne szlaki komunikacyjne w strefie chetmińsko-dobrzyńskiej w X-XI wieku, [w:] Benedyktyńska praca. Studia historyczne ofiarowane O. Pawłowi Sczanieckiemu w 80-rocznice urodzin, red. O. J. A. Spież, oprac. Z. Wielgosz, Kraków-Tyniec, s. 101-118. 
1997b Wczesnośredniowieczny szlak komunikacyjny z Kujaw do Prus - studium archeologiczne, [w:] Wczesnośredniowieczny szlak lądowy z Kujaw do Prus (XI wiek). Studia i materiaty, red. W. Chudziak, Toruń, s. 9-31.

2001 Wczesnośredniowieczne groby komorowe z Kałdusa pod Chetmnem na Pomorzu Wschodnim, Slavia Antiqua, t. 42, s. 63-96.

Chudziak W., Kaźmierczak R.

2013 Zdobnictwo przedmiotów drewnianych z Żóttego na Pomorzu Zachodnim jako przykład tzw. pomorskiej szkoły ornamentyki skandynawsko-insularnej, Archaeologia Historica Polona, t. 21, s. 7-30.

Drozd A., Janowski A., Poliński D.

2009 Wczesnośredniowieczne groby komorowe na cmentarzysku w Pniu koło Bydgoszczy (badania 2005-2007), [w:] XVI Sesja Pomorzoznawcza, 22-24.11.2007 r., Szczecin, cz. 1: Od epoki kamienia do okresu wczesnośredniowiecznego, red. A. Janowski, S. Słowiński, K. Kowalski, Acta Archaeologica Pomoranica 3, Szczecin, s. 351-366.

2011 Badania ratownicze przeprowadzone w 2009 roku na średniowieczno-nowożytnym cmentarzysku w Pniu, gm. Dąbrowa Chetmińska, woj. kujawsko-pomorskie (stanowisko 9), [w:] XVII Sesja Pomorzoznawcza, t. 1: Od epoki kamienia do wczesnego średniowiecza, red. M. Fudziński, H. Paner, Gdańsk, s. 513-521.

Duczko W.

2000 Obecność skandynawska na Pomorzu i słowiańska w Skandynawii we wczesnym średniowieczu, [w:] Salsa Cholbergiensis. Kołobrzeg we wczesnym średniowieczu, red. L. Leciejewicz, M. Rębkowski, Kołobrzeg, s. 23-44.

Janowski A.

2007 Quondam castrum Ruth-próba lokalizacji średniowiecznego grodu w ziemi chetmińskiej $w$ świetle źródet pisanych $i$ archeologicznych, AHP, t. 17, s. 278-292.

2010 Jeżeli umrze ktoś znaczny z nich, kopia dlań grób podobny do obszernego domu... kilka uwag o tzw. grobach komorowych na terenie Europy Środkowej i Wschodniej, [w:] In sivis, campis... et urbe, średniowieczny obrzadek pogrzebowy na pograniczu polsko-ruskim, red. S. Cygan i in., Rzeszów-Sanok, s. 385-402.

Kiersnowscy R., T.

1959 Wczesnośredniowieczne skarby srebrne z Pomorza, Wrocław.

Kola A.

1991 Grody ziemi chetmińskiej w późnym średniowieczu, Torun.

Kołodziejski S.

1992 Wstęp do studiów nad geneza obronnych rezydencji możnowładczych, [w:] Stan i potrzeby badań nad wczesnym średniowieczem $w$ Polsce. Materiały z konferencji, Poznań 14-16 grudnia 1987 roku, red. Z. Kurnatowska, Poznań-Wrocław-Warszawa, s. 275-282. 
Kowalewski J.

2003 Kontakty regionalne ziemi chetmińskiej we wczesnym średniowieczu w świetle struktury miejscowych depozytów srebrnych, [w:] Studia nad osadnictwem średniowiecznym ziemi chetmińskiej, t. 5, red. W. Chudziak, Toruń, s. 151-186.

Lewicki T.

1972 Handel Samanidów ze wschodnia i środkową Europa, Slavia Antiqua, t. 19, s. $1-18$.

Lissauer A.

1887 Die prähistorischen Denkmäler der Provinz Westpreussen, Leipzig.

Łęga W.

1930 Kultura Pomorza we wczesnem średniowieczu na podstawie wykopalisk, Torun.

Łosiński W.

1988 Chronologia napływu najstarszej monety arabskiej na terytorium Europy, Slavia Antiqua, t. 31, s. 93-181.

2002 W sprawie ,wschodniej drogi” doptywu monet arabskich do Wielkopolski $w$ X wieku, [w:] Moneta mediaevalis. Studia numizmatyczne i historyczne ofiarowane Profesorowi Stanisławowi Suchodolskiemu w 65. rocznice urodzin, red. R. Kiersnowski i in. Warszawa, s. 185-192.

Łowmiański H.

1985 Poczatki Polski. Polityczne i społeczne procesy kształtowania się narodu do początku wieku XIV, t. 6, Warszawa.

Łukasiak J.

1999 Wczesnośredniowieczna zapinka podkowiasta z Napola, stanowisko 6, woj. kujawsko-pomorskie, [w:] Studia nad osadnictwem średniowiecznym ziemi chetmińskiej, red. W. Chudziak, Toruń, s. 257-287.

Ossowski G.

1878 O pomnikach przedhistorycznych Prus Królewskich, Roczniki Towarzystwa Naukowego w Toruniu, t. 1, Toruń.

Piotr z Dusburga

2004 Piotr z Dusburga, Kronika ziemi pruskiej, tłum. S. Wyszomirski, wstęp i komentarz J. Wenta, Toruń.

Poliński D.

1994 Napole, gm. Kowalewo Pomorskie, [w:] Wczesnośredniowieczne grodziska ziemi chetmińskiej. Katalog źródet, red. J. Chudziakowa, Toruń, s. 115-124.

1996 Przemiany $w$ wytwórczości garncarskiej na ziemi chetmińskiej u schyłku wczesnego i na początku późnego średniowiecza, AHP, t. 4, Toruń.

2001 Źródła archeologiczne do studiów nad późnośredniowiecznym osadnictwem wiejskim w ziemi chetmińskiej, AHP, t. 11, Toruń.

2003 Późnośredniowieczne osadnictwo wiejskie $w$ ziemi chetmińskiej, Toruń.

Powierski J.

1973a Studia nad struktura administracyjno-terytorialna ziemi chetmińskiej i michałowskiej w okresie piastowskim, Bydgoskie Towarzystwo Naukowe, Prace Wydziału Nauk Humanistycznych, seria C, nr 13, Prace Komisji Historii 9, s. 3-86. 
1973b Ostrowicko-golubski kompleks osadniczy i problem jego stosunków własnościowych w okresie przedkrzyżackim, Acta Universitatis Nicolai Copernici, Historia, t. 9, s. 45-58.

1977 Dobra ostrowicko-golubskie biskupstwa włoctawskiego na tle stosunków polsko-krzyżackich w latach 1235-1308, Gdańsk.

Stanisławski B.

2013 Jómswikingowie z Wolina-Jómsborga-studium archeologiczne przenikania kultury skandynawskiej na ziemie polskie, Wrocław.

Stawska V.

1993 Komunikat z badań wczesnośredniowiecznego cmentarzyska w Napolu, gm. Kowalewo Pomorskie, woj. toruńskie, stan. 6, [w:] Badania archeologiczne ośrodka toruńskiego w latach 1989-1992, red. J. Chudziakowa, Toruń, s. 139-144.

2003 Cmentarzyska wczesnośredniowieczne z ziemi chetmińskiej wświetle najnowszych badań, [w:] Studia nad osadnictwem średniowiecznym ziemi chetmińskiej, t. 5, red. W. Chudziak, Toruń, s. 89-108.

Wyrozumski J.

1988 Historia Polski do roku 1505, Warszawa.

\section{STRONGHOLD IN OSTROWITE (NAPOLE) IN CHEŁMNO LAND - FROM OPOLE CENTRE TO KNIGHT ESTATE}

\section{Summary}

The Ostrowite settlement complex consists of: stronghold (site 1) - known from written sources stronghold in Ostrowite (castrum Ostrowith), two extensive settlements, inhumation burial ground and several smaller settlement points located along the north shore of Lake Oszczywilk and subglacial tunnel valleys stretching west towards Kowalewo and south-east - towards Golub nad Drwęcą. The name of stronghold was mentioned in longer version of the privilege of Lonyz (version A from about 1240). In older literature on this subject wrote Godfryd Ossowski (1878), Abraham Lissauer (1887), Władysław Łęga (1930). Excavations, conducted in 1976, 1989, 1990-1994, covered all the most important parts of the settlement complex. The results of this work became the subject of a separate publication (Bojarski 2012).

Development of strong settlement structures at Lake Oszczywilk coincided with the time of disintegration of mesoregion community situated at the Struga Rychnowska River around the stronghold in Gronowo playing role of a central place. Its dynamic development was supported by both advantageous location - large patches of fertile soil, surrounded by less fertile outwash plains and podzolic soils covered with broad zones of forests, constituting natural settlement barriers, as well as communication conditions, including the vicinity of the Drwęca River. This river from the very beginning of the early Middle Ages was a 'transmission belt' along which the population inhabiting areas on both its banks migrated. The settlement centre in the area of today's Napole/Ostrowite played an important role in the exchange realized along the east-west line (trade route connecting Pomerania with Rus' through Mazovia and Chełmno Land) and north-south 
(Kuyavia with Old Prussia). It was favoured by advantageous location at natural waterways linked directly to the Drwęca River (the Struga Młyńska River and the Ruziec River) and facilitating the connection between Chełmno Land and Dobrzyń Land. The boundaries of the subsequent Ostrowite/Golub centre clearly distinguish against the background of settlement map of south-east part of Chełmno Land and adjacent northern part of Dobrzyń Land. Aperceptible centre, consisting initially of a large settlement and then a stronghold (formed in the second half of the $10^{\text {th }}$ century) as well as related settlements, creating a real core of a microregion type community, was surrounded in various periods by more than 10 (from 13 to 20) settlement points situated between the centre and the periphery. In tribal times they formed a territorial unit of opole type, while in younger stages of the early Middle Ages a stronghold district in the administration system of Piast state. The surface of this unit - the property of the bishopric of Włocławek known from later written sources, named by Jan Powierski Ostrowite-Golub estate - was about 140-160 km², which corresponds to the size of $1000 \mathrm{lan}$, stated in a document from 1276. The boundaries of the Ostrowite estate, and yet the most intensively exploited by this community territory, are defined very clearly by areas devoid of settlement, visible at a distance of 4-6 km from the centre located at Lake Oszczywilk, as well as in the forest zone, still preserved along the Drwęca River and the Struga Rychnowska valleys. In addition, the boundaries symbolically are hiding places of hoards from Golub, Kowalewo, and Rychnowo, which fit in zones separating the neighbouring settlement units. The end of this structure was formation at its outskirts of two military and administrative centres of the Teutonic Knights state - in Kowalewo and Golub, which after 1293 took over the functions of the former stronghold in Ostrowite. 
